\title{
Medicinal and Pesticidal Potentials of the Constituents of the Essential Oil from Adenia cissampeloides Leaves
}

\author{
M. Ogunlesi, W. Okiei, E. Ofor, and A. Eniola \\ Chemistry Department, University of Lagos, Lagos, Nigeria
}

DOI: $10.15255 / K U I .2018 .027$

KUI-2/2019

Review

Received April 28, 2018

Accepted July 20, 2018

\begin{abstract}
Adenia cissampeloides (Planch. ex Hook.) Harms is used in alternative medicine primarily for the management of hypertension and several other diseases. Isolation and GC-MS analysis of five essential oils collected fractionally and over $4 \mathrm{~h}$ by hydrodistillation from the dried leaves were carried out. The constituents included phytol, $\alpha$-linolenic acid, $n$-hexadecanoic acid, hexahydrofarnesyl acetone, (13S)-8,13-epoxy-labd-14-ene, kaur-16-ene, guaiol, $\alpha$-gurjunene, and $\alpha$-elemene. Several bioactivities of the constituents as well as their potential applications in medicine and the pharmaceutical and pesticidal industries are discussed. Essential oils from some other plants have several constituents in common with those isolated from A. cissampeloides. The bioactivities of such plants are used to suggest other possible applications of A. cissampeloides.
\end{abstract}

Keywords

Adenia cissampeloides, GC-MS, medicinal plants, essential oil, bioactivity

\section{Introduction}

The uses of plants as medication for various health conditions are found in several countries of the world, including Nigeria. ${ }^{1}$ In the practice of alternative medicine, medicinal plants have been used for the management of numerous health conditions, and useful bioactive agents have been found present in various plant extracts, including essential oils. For example, Sesamum radiatum, a plant used to improve fertility in male subjects, contains a yohimbine derivative which has been suggested as the relevant bioactive agent. ${ }^{2}$ Cissus populnea is also used for the same purpose, and extracts from the stem have been found to promote appreciable proliferation of Sertoli cells from rats. ${ }^{3}$ The essential oils from Euphorbia hirta and Calotropis procera, plants used in the management of asthma, have been found to be rich in phytol, an anti-inflammatory compound. . $^{4-6}$

Adenia cissampeloides (Planch. ex Hook.) Harms, commonly known as monkey rope or snake climber or Adenia, belongs to the Passifloraceae family. It grows in tropical and subtropical regions. The acclaimed use of the plant in Nigeria is in the management of hypertension. It has also been found useful in the treatment of nervous disorders, leprosy, stress, cough, gonorrhoea, as well as antimicrobial treatment for wounds and sores. ${ }^{7}$ The roots, leaves, and stem-bark are usually employed as curative agents. The sap is also used as a facial cosmetic. A catalogue of various uses of the plant worldwide contains additional medicinal applications of the various plant parts, which are sometimes used singly or in combination with other parts of the plant. These include an infusion of the root, stem or leaves in treating various ailments, including headache and back pain. The roots in various preparations are used in the treatment of fever, malaria, scabies, cholera, anaemia and

*Corresponding author: Professor Modupe Ogunlesi, B. Sc. Ph. D. email: mayogunlesi@yahoo.com snake bites. They are also used as diuretic, abortifacient and arrow poison. Bees have been found to be passive when exposed to smoke from the burning roots. The roots in combination with the stem are administered to humans in order to expel intestinal worms. This mixture is also used for the management of venereal diseases and sterility. The leaves have been reported useful as an antipyretic and for the management of malaria, liver ailments, fractures, bronchitis, lung ailments, depression, and insanity. The bark has also been found useful in inducing amnesia and treating scabies. The stem has been employed as fish poison. ${ }^{8}$ The phytochemical constituents reported present in A. cissampeloides include tannins, which have antibacterial and anti-inflammatory activity, saponins, phlobatannins, terpenoids, steroids, alkaloids, carbohydrates, glycosides, which may lower blood pressure, and flavonoids, which may exhibit diuretic and antibacterial activity. ${ }^{9}$ Tetraphyllum B, a cyanogen glycoside, has been isolated from the roots of the plant. ${ }^{10}$ The aqueous extract of a herbal preparation obtained from $A$. cissampeloides was administered to seven female patients in Ghana, and the systolic blood pressure was significantly lower in subjects on A. cissampeloides compared to control subjects not on the medication. ${ }^{11}$

Hypertension is a major health problem in black populations. The symptoms of hypertension include severe headaches, chest pain, breathing problems, irregular heartbeats, and dizziness. ${ }^{12,13}$ Persistent hypertension is a risk factor for heart failure, stroke, and myocardial infarction, and is a major cause of chronic kidney failure. ${ }^{14} \mathrm{~A}$ single medication, sometimes combined with another, is often administered to hypertensive patients in order to maintain the blood pressure below 140/90. However, there are incidences of resistant hypertension in which concurrent use of three anti-hypertensive medications of different classes do not keep the blood pressure below this value..$^{15}$ This calls for further intensive search for anti-hypertensive medications, possibly of plant origin. 
In this study, the isolation and GC-MS analyses of the essential oils from the leaves of $A$. cissampeloides have been carried out primarily for identifying possible constituents that may reduce blood pressure, and other constituents that may be useful for the management of various health disorders for which A. cissampeloides is employed in alternative medicine. The occurrences and bioactivities of several constituents and their current and potential applications in the pharmaceutical industry and medicine are discussed. Other possible applications of A. cissampeloides are suggested based on comparison of the constituents of the essential oils of the plant with those from other plants.

\section{Experimental}

\subsection{Plant procurement and processing}

Fresh leaves of the Adenia cissampeloides (Planch. ex Hook.) Harms were obtained from vendors of medicinal plants in Mushin market in Lagos. The plant was identified by Mr. T. K. Odewo, formerly of the Department of Botany of the Forestry Research Institute of Nigeria, Ibadan, where vouchers were deposited and assigned the number FHI 107683. The leaves were cut into small pieces and dried at room temperature in a dust-free environment in the laboratory, after which pulverization was carried out.

\subsection{Isolation of essential oils}

The essential oils were obtained by hydrodistillation using Clevenger apparatus. The procedure for isolation of the essential oils has been described in a previous report. ${ }^{5}$ Two modes of collection were employed. In one mode, the essential oil was collected hourly into hexane over a period of $4 \mathrm{~h}$. In another mode, the essential oil was collected over a period of $4 \mathrm{~h}$. The colour of the fractions in hexane increased in intensity from light orange for the first hour collection to deep orange for the $4^{\text {th }}$ hour collection.

\subsection{GC-MS analysis of the essential oils}

Analysis was carried on GC-MS model 7890A, Agilent Technologies, fitted with an HP-5MS column (30 $\mathrm{m} \times 0.25 \mathrm{~mm}, 0.25 \mu \mathrm{m})$; carrier gas was helium at a flow rate of $1 \mathrm{ml} \mathrm{min}^{-1}$, and a temperature program $50{ }^{\circ} \mathrm{C}$ (1 min) $\rightarrow 300{ }^{\circ} \mathrm{C} \mathrm{min}^{-1}$ at $8{ }^{\circ} \mathrm{min}^{-1}$ (5 min) was employed. Mass spectra were obtained on spectrometer model 5975 VLMSD. Identification of the compounds was carried out using the ChemStation software and the NIST 08 library in the instrument. The compound in the library with a minimum spectral match of $90 \%$ compared with that of the constituent eluted from the GC was selected as the corresponding compound.

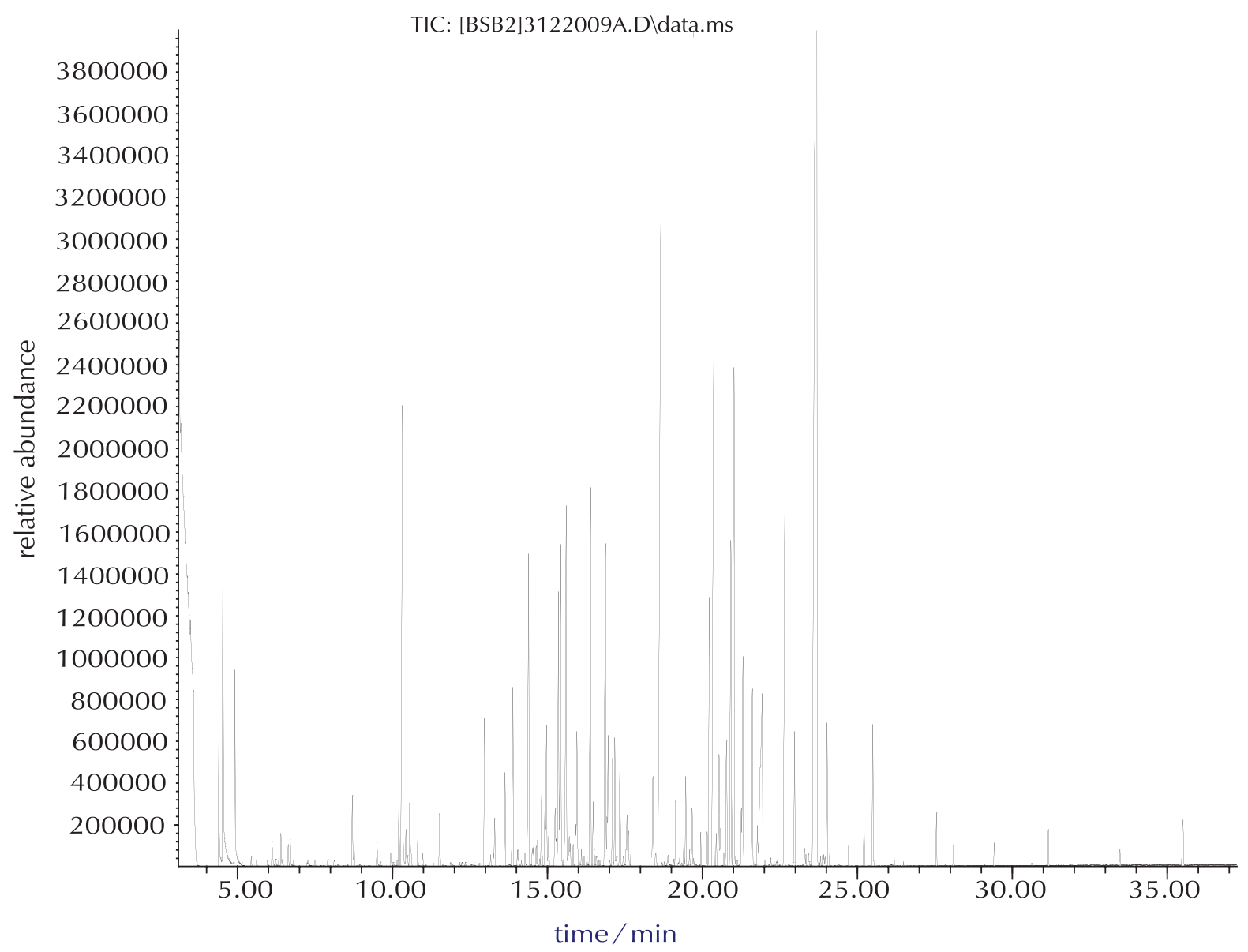

Fig. 1 - Chromatogram of the essential oil from the leaves of $A$. cissampeloides collected in $4 \mathrm{~h}$ 


\section{Results and discussion}

The chromatogram for the essential oil collected in $4 \mathrm{~h}$ is shown in Fig. 1, while constituents in all five essential oil samples are presented in Table I. The constituents include terpenes, oxygenated terpenes, alcohols, heterocyclic compounds, hydrocarbons, aldehydes, ketones, saturated and unsaturated fatty acids, and fatty acid methyl esters. Several of the constituents of the leaf essential oil of Adenia cissampeloides (Planch. ex Hook.) Harms, such as azulene, myrtenol, camphene, cubebene, $\alpha$-humulene, fatty acids, alcohols, aldehydes, secondary ketones, phytol, and phenolics are typical compounds found in essential oils. The major constituent in the essential oil samples is phytol. Other constituents include $\alpha$-linolenic acid, $n$-hexadeca- noic acid, hexahydrofarnesyl acetone, (13S)-8,13-epoxylabd-14-ene, kaur-16-ene, guaiol, $\alpha$-gurjunene and $\alpha$-elemene. The major compound in the essential oil isolated in the $1^{\text {st }}$ hour was germacrene D and 1,13-tridecanediol, diacetate in the $2^{\text {nd }}$ hour. (13S)-8,13-epoxy-labd-14-ene and phytol were the major compounds in the $3^{\text {rd }}$ hour, $n$-hexadecanoic acid and phytol in the $4^{\text {th }}$ hour, and phytol in the sample collected over $4 \mathrm{~h}$. The medicinal and pharmaceutical applications of several of these constituents are here discussed. Essential oils from some plants were observed to have several constituents in common with those isolated from $A$. cissampeloides. The bioactivities of such plants are used to suggest other possible applications of $A$. cissampeloides.

Table 1 - Constituents of the essential oils from the leaves of $A$. cissampeloides

\begin{tabular}{|c|c|c|c|c|c|c|c|}
\hline \multirow[t]{2}{*}{$\mathrm{S} / \mathrm{No}$} & \multirow[t]{2}{*}{$R_{\mathrm{T}} / \min$} & \multirow[t]{2}{*}{ Compound } & \multicolumn{5}{|c|}{ Percentage of total } \\
\hline & & & $1^{\text {st }} \mathrm{h}$ & $2^{\text {nd }} \mathrm{h}$ & $3^{\text {rd }} \mathrm{h}$ & $4^{\text {th }} \mathrm{h}$ & $4 \mathrm{~h}$ \\
\hline 1. & 6.40 & tSabinene & - & - & - & - & 0.2 \\
\hline 2. & 6.70 & 1-ethyl-3-methylbenzene & - & - & - & - & 0.2 \\
\hline 3. & 8.77 & 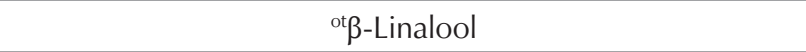 & 1.1 & - & - & - & - \\
\hline 4. & 10.21 & ${ }^{\mathrm{ot} T e r p i n e n-4-o l}$ & - & - & - & - & 0.4 \\
\hline 5. & 10.35 & Azulene & 1.9 & 1.3 & - & - & 3.8 \\
\hline 6. & 10.53 & ${ }^{\mathrm{ot}} \alpha$-Terpineol & 1.0 & - & - & - & - \\
\hline 7. & 10.64 & ot(-)-Myrtenol & 2.3 & - & - & - & - \\
\hline 8. & 12.27 & Indole & - & - & - & 0.4 & - \\
\hline 9. & 12.97 & ${ }^{\mathrm{t}} \gamma$-Elemene & - & - & - & - & 0.9 \\
\hline 10. & 13.03 & 2,5,5-Trimethyl-1,3,6-heptatriene & - & 1.5 & - & - & - \\
\hline 11. & 13.08 & tCamphene & 3.7 & - & - & - & - \\
\hline 12. & 13.32 & o-Eugenol & - & 0.6 & 0.3 & 0.8 & - \\
\hline 13. & 13.72 & ${ }^{\mathrm{t}} \alpha$-Cubebene & 1.9 & - & - & - & 0.5 \\
\hline 14. & 13.95 & ${ }^{\mathrm{t}} \beta$-Elemene & 3.9 & 1.7 & - & - & - \\
\hline 15. & 14.39 & ${ }^{\mathrm{t} C a r y o p h y l l e n e}$ & - & - & - & - & 2.2 \\
\hline 16. & 14.50 & t4,8,8-Trimethyl-2-methylene-4-vinylbicyclo[5.2.0]nonane, & & 2.4 & - & 0.5 & - \\
\hline 17. & 14.62 & t2-Isopropyl-5-methyl-9-methylene-bicyclo[4.4.0]dec-1-ene & 1.2 & - & - & - & 1.7 \\
\hline 18. & 14.69 & tAlloaromadendrene & - & - & - & - & 0.2 \\
\hline 19. & 14.94 & Geranylacetone & 1.5 & - & - & - & 0.5 \\
\hline 20. & 15.00 & 2,6-Diaminopyridine & - & - & 2.3 & - & - \\
\hline 21. & 15.04 & ${ }^{\mathrm{t}} \alpha$-Humulene & 2.8 & - & - & - & - \\
\hline 22. & 15.04 & ${ }^{\mathrm{t}} \beta$-Gurjunene & - & - & - & - & 0.2 \\
\hline 23. & 15.25 & ${ }^{\mathrm{t}} \alpha$-Amorphene & - & - & - & - & 0.6 \\
\hline 24. & 15.32 & ${ }^{t} \gamma$-Muurolene & - & 0.6 & - & - & - \\
\hline 25. & 15.40 & ${ }^{\mathrm{t}} \beta$-Cubebene & - & - & - & 1.1 & - \\
\hline 26. & 15.44 & ${ }^{\mathrm{t}}$ Germacrene D & 11 & 6.5 & - & - & - \\
\hline 27. & 15.54 & $\beta$-Ionone & - & - & - & - & 2.3 \\
\hline 28. & 15.68 & tBicyclogermacrene & 3.6 & 3.8 & - & - & - \\
\hline 29. & 15.70 & ${ }^{t} \delta$-Guaiene & - & - & - & - & 0.3 \\
\hline 30. & 16.08 & ${ }^{\mathrm{t}} \delta$-Cadinene & 2.3 & 1.4 & 0.5 & 0.6 & 1.1 \\
\hline 31 & 16.41 & ${ }^{\text {otElemol }}$ & - & - & 2.1 & 1.1 & 2.8 \\
\hline
\end{tabular}


Table 1 - (continued)

\begin{tabular}{|c|c|c|c|c|c|c|c|}
\hline \multirow[t]{2}{*}{$\mathrm{S} / \mathrm{No}$} & \multirow[t]{2}{*}{$R_{\mathrm{T}} / \min$} & \multirow[t]{2}{*}{ Compound } & \multicolumn{5}{|c|}{ Percentage of total } \\
\hline & & & $1^{\text {st }} \mathrm{h}$ & $2^{\text {nd }} h$ & $3^{\text {rd }} \mathrm{h}$ & $4^{\text {th }} \mathrm{h}$ & $4 \mathrm{~h}$ \\
\hline 32. & 16.89 & ot(-)-Spathulenol & - & - & - & 1.3 & - \\
\hline 33. & 16.99 & ${ }^{\text {ot } C a r y o p h y l l e n e ~ o x i d e ~}$ & - & - & 0.4 & - & 1.1 \\
\hline 34. & 17.16 & ot(+)-Spathulenol & 3.4 & 4.7 & 1.4 & - & 2.7 \\
\hline 35. & 17.16 & ${ }^{\text {ot }}$ Guaiol & 2.6 & 1.4 & 0.5 & - & - \\
\hline 36. & 17.22 & 1,12-Dodecanediol & - & - & - & 0.6 & - \\
\hline 37. & 17.23 & trans-2-Dodecen-1-ol & - & - & 0.9 & - & 0.8 \\
\hline 38. & 17.67 & ${ }^{\mathrm{ot}} \gamma$-Eudesmol & - & - & 0.5 & - & - \\
\hline 39. & 17.95 & 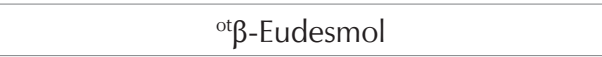 & - & - & - & 0.9 & - \\
\hline 40. & 18.02 & ${ }^{t} \gamma$-Gurjunene & - & - & 4.9 & - & 3.4 \\
\hline 41. & 18.04 & ${ }^{\mathrm{t}} \alpha$-Gurjunene & 1.8 & 7.2 & - & - & - \\
\hline 42. & 18.12 & Cyclotetradecane & - & - & - & 0.3 & - \\
\hline 43 & 18.14 & ${ }^{t} \alpha$-Elemene & 6.3 & & & 2.5 & - \\
\hline 44. & 18.14 & Cyclodecane & - & - & 1.0 & - & - \\
\hline 45. & 18.53 & Tetradecanal & 5.1 & - & 1.6 & - & - \\
\hline 46. & 18.65 & Pentadecanal & - & - & - & - & 6.9 \\
\hline 47. & 18.71 & (E)-2-Tridecen-1-ol & - & - & - & 6.5 & - \\
\hline 48. & 18.73 & 11-Tetradecyn-1-ol-acetate & - & - & 5.9 & - & - \\
\hline 49. & 18.76 & 1,13-Tridecanediol diacetate & - & 7.9 & - & - & - \\
\hline 50. & 19.46 & 1-Hexadecanol & & & & & 0.7 \\
\hline 51. & 19.51 & Benzyl Benzoate & 0.6 & 0.7 & 0.7 & 0.5 & 0.6 \\
\hline 52. & 19.52 & 1,13-Tetradecadiene & - & - & - & 1.5 & - \\
\hline 53. & 19.73 & cis,cis,cis-7,10,13-Hexadecatrienal & - & - & 1.0 & - & - \\
\hline 54. & 20.01 & 18-Nonadecen-1-ol & - & - & 0.5 & - & - \\
\hline 55. & 20.47 & Hexahydrofarnesyl acetone & 2.1 & 4.4 & 5.1 & 5.0 & 4.8 \\
\hline 56. & 20.51 & (Z)6, (Z)9-Pentadecadien-1-ol & - & - & 0.3 & - & - \\
\hline 57. & 20.71 & faPentadecanoic acid & - & - & 0.8 & - & - \\
\hline 58. & 20.86 & 1,4-Ecosadiene & - & - & 0.8 & - & - \\
\hline 59. & 20.99 & cis,cis-7,10-Hexadecadienal & - & - & - & 5.3 & - \\
\hline 60. & 21.12 & ${ }^{\text {usfa }} \alpha$-Linolenic acid & - & - & 5.6 & 6.8 & - \\
\hline 61. & 21.61 & ot3,5,11,15-tetramethyl hexadec-1-en-3-ol- & - & - & - & - & 1.0 \\
\hline 62. & 21.70 & otlsophytol & - & - & 2.3 & - & - \\
\hline 63. & 21.93 & ${ }^{\text {fan}} n$-Hexadecanoic acid & - & 0.5 & 0.7 & 8.9 & 3.1 \\
\hline 64. & 22.48 & tKaur-15-ene & - & - & 0.2 & - & - \\
\hline 65. & 22.76 & (13S)-8,13-epoxy-labd-14-ene & - & 6.4 & 7.2 & 6.9 & 2.4 \\
\hline 66. & 22.98 & tKaurene & - & - & - & - & 0.8 \\
\hline 67. & 23.08 & tKaur-16-ene & 1.7 & 2.2 & 2.6 & 2.3 & - \\
\hline 68. & 23.41 & fame Linoleic acid methyl ester & & & 0.7 & & \\
\hline 69. & 23.41 & usfa Linoleic acid & - & - & - & 0.7 & - \\
\hline 70. & 23.48 & fameOleic acid, methyl ester & - & - & 1.1 & 1.6 & - \\
\hline 71. & 23.70 & otPhytol & 2.8 & 7.6 & 7.2 & 8.9 & 19.7 \\
\hline 72 & 23.89 & usfaLinoleic acid & - & - & - & 0.4 & - \\
\hline 73. & 23.89 & usfa Oleic acid & & & & 1.7 & \\
\hline 74. & 23.93 & {$[(2,4,6$-Triethylbenzoyl)thio]-acetic acid } & - & - & 1.4 & & - \\
\hline
\end{tabular}


Table 1 - (continued)

\begin{tabular}{|c|c|c|c|c|c|c|c|}
\hline \multirow[t]{2}{*}{$\mathrm{S} / \mathrm{No}$} & \multirow[t]{2}{*}{$R_{\mathrm{T}} / \min$} & \multirow[t]{2}{*}{ Compound } & \multicolumn{5}{|c|}{ Percentage of total } \\
\hline & & & $1^{\text {st }} \mathrm{h}$ & $2^{\text {nd }} \mathrm{h}$ & $3^{\text {rd }} \mathrm{h}$ & $4^{\text {th }} \mathrm{h}$ & $4 \mathrm{~h}$ \\
\hline 75. & 24.22 & 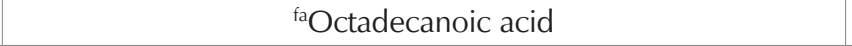 & - & - & 1.2 & 0.9 & - \\
\hline 76. & 25.30 & ${ }^{\mathrm{ot} K a u r a n-16-o l}$ & - & 1.1 & - & - & 0.3 \\
\hline 77. & 25.33 & ot16.ß.H-Kauran-16-ol & - & - & 2.4 & - & - \\
\hline 78. & 25.50 & 1,2-Benzisothiazole,3-(hexahydro-1H-azepin-1-yl)-,1,1-dioxide & - & - & - & - & 0.8 \\
\hline 79. & 27.62 & 1-lodooctadecane & - & - & 0.3 & - & 0.1 \\
\hline \multirow[t]{2}{*}{80.} & 31.17 & 9-Butyldocosane & - & - & - & - & 0.2 \\
\hline & & Total & 67.8 & 63.9 & 64.4 & 67.0 & 66.3 \\
\hline
\end{tabular}

Key: $\mathrm{t}=$ terpene, ot $=$ oxygenated terpene, $\mathrm{fa}=$ fatty acid, $\mathrm{usfa}=$ unsaturated fatty acid, fame $=$ fatty acid methyl ester.

Sabinene is a monoterpene and is the subject of several patents. Monoterpenes have been found to exhibit several pharmacological properties, including antifungal, antibacterial, antioxidant, anticancer, and antispasmodic activities. ${ }^{16}$ This constituent, when incorporated in some compounds, has been found to have great medicinal potentials. When it occurs in natural compounds, its possible roles can thus be considered. For example, it is useful in the enhancement of activity of antibiotics. Oxazolidinone antibiotics are known to be active against multi-drug resistant Gram-positive organisms. They are not cross-resistant with other antibiotics. ${ }^{17-18}$ In an invention, oxazolidinones having a bicyclic[3.1.0] hexane-containing moiety were found to be effective against aerobic, anaerobic pathogens including multi-resistant staphylococci, streptococci, and enterococci, bacteroides species, clostridia species as well as acid-fast organisms, such as Mycobacterium tuberculosis and other mycobacterium species which are implicated in leprosy. ${ }^{19} \mathrm{~A}$ study based on the work of Basile et al. ${ }^{20}$ and Skolnick et al. ${ }^{21}$ provides novel 1-heteroaryl-3-azabicyclo[3.1.0] hexanes and similar processes and intermediates for synthesizing such compounds and compositions and methods using the compounds for the treatment or prevention of central nervous system (CNS) disorders, including depression and anxiety. Some experiments ${ }^{22}$ based on studies carried out by P. Skolnick et al. ${ }^{23}$ and M. Briley ${ }^{24}$ showed that phenyl substituted-3-azabicyclo[3.1.0] hexanes inhibited the reuptake of biogenic amines that serve as neurotransmitters in the CNS. Therefore, compounds which inhibit the reuptake of these neurotransmitters may be useful as antipsychotic agents, effective in treating CNS disorders, including drug dependency. Bicyclic compounds have also been reported to be nicotinic acetylcholine receptor inhibitors, and have been found useful for the treatment of clinical conditions, such as anxiety, Alzheimer disease, depression, convulsive disorders, cognitive memory disorders, Attention Deficient Disorder/Hyperactivity Syndrome, inflammation, pain, psychosis, mania, Parkinson's disease, sleep disorders, and disorders of the CNS related to or affected by certain nicotinic receptors. ${ }^{25-29}$ These bicyclic [3.1.0] hexane-containing moiety and derivatives have not been reported present in any extract of A. cissampeloides, but the presence of this constituent in the essential oil suggests the potential of the plant for the management of nervous disorder, stress, venereal diseases, and leprosy. ${ }^{7,8}$
$\beta$-Linalool is a terpene alcohol. In a review article, it was reported that monoterpenes have been found to exhibit significant effects on the cardiovascular system ${ }^{30}$ in addition to those listed previously. ${ }^{16}$ In a study on the effect of the optical isomers of linalool on human subjects, it was observed that while (+)-linalool exhibited stimulating effect on the cardiovascular system, (-)-linalool exhibited a depressing effect. ${ }^{31}$ Linalool is usually found in the racemic form in nature. $( \pm)$-Linalool has been reported to induce hypotension associated with tachycardia in rats. ${ }^{32}$ Thus, this constituent may cause the reduced systolic blood pressure observed in hypertensive human subjects who were treated with herbal preparations of the plant. ${ }^{11}$ Several patents have been filed on the various applications of linalool. One of such is on the control of ticks and fleas with linalool. ${ }^{33}$ The patent is based on a report on the inhibition of houseflies by certain terpenoids. ${ }^{34}$ Thus, A. cissampeloides may function as a broad-based insecticide not limited to scabies. This constituent is also present as the major volatile constituent (15.6\%), of Thea viridis, green tea, ${ }^{35}$ and in the essential oil of the oleo-gum resin of Frankincense, Boswellia species (6.64 \%), which has been identified for its immune-enhancing, antibacterial, antifungal, antiviral, antiseptic, wound healing, anti-inflammatory, and anti-cancer properties. ${ }^{36}$ Some of these bioactivities may be exhibited by $A$. cissampeloides.

F. Mondello et al. ${ }^{37}$ established the efficacy of terpinen-4-ol, the main component (30\% minimum) of Melaleuca alternifolia Cheel (tea tree oil), against human pathogenic Candida species which were azole-susceptible and -resistant. The susceptibility of Legionella pneumophila, one of the microorganisms implicated in Legionnaire's disease, to $M$. alternifolia oil, was also reported. ${ }^{38}$ These studies ${ }^{37,38}$ formed the basis of a patent ${ }^{39}$ which refers to the use of terpinen-4-ol, both aqueous solution and vapour forms as antimicrobial agent against bacteria of Legionella genus, preferably $L$. pneumophila for disinfecting systems for the distribution of water in various facilities. Terpinen-4-ol is reported to be the major constituent of the essential oil from Alpinia zerumbet or Alpinia speciosa (Blume) D. Dietr, which is widely used as a tea in the management of arterial hypertension in alternative medicine. ${ }^{30} \mathrm{~S}$. Lahlou et al. ${ }^{40,41}$ reported the cardiovascular and antihypertensive effects of terpinen-4-ol, and concluded that the hypotensive effects of the essential oil are partially attributed to the actions of terpinen-4-ol. Thus, this constituent has antihypertensive 
activity and may contribute to the observed antihypertensive activity of $A$. cissampeloides. ${ }^{11}$

Azulene has been recognized for its soothing effect, anti-inflammatory activity, and several medicinal applications. Its anti-inflammatory activity has been demonstrated in several animal models. ${ }^{42} \mathrm{~A}$ derivative, chamazulene carboxylic acid, is a natural profen with anti-inflammatory activity. ${ }^{43}$

$\alpha$-Terpineol is irritating to eyes, respiratory system, and skin. It constitutes $0.3 \%$ of the essential oil sample collected over a period of four hours. $\alpha$-Terpineol has been reported to exhibit a hypotensive effect in rats and also induce vasorelaxation. ${ }^{44,45}$ These two effects have been confirmed and possible pathways proposed for the effects. ${ }^{46} \alpha$-Terpineol has been reported to exhibit antioxidant, antiseptic, anti-hypernociceptive and anti-inflammatory activity ${ }^{47,48}$, and may confer some of these bioactivities on the plant essential oil.

(-)-Myrtenol, a bicyclic monoterpene alcohol, has been reported to exhibit hypotensive effects at doses of I $\mathrm{mg} \mathrm{kg}^{-1}$ when administered intravenously in rats. ${ }^{44}$ It may function in a similar manner in human subjects.

Indole is a precursor to many pharmaceutical products, and the indole core is commonly found in several varieties of biologically active compounds. ${ }^{49}$ Indole structures are able to bind many receptors in the body and hence are considered privileged structure motifs. ${ }^{50}$ Thus, a great deal of research has been dedicated to incorporate indole in the synthesis of new anti-mitotic compounds for the treatment of cancer. One of such compounds, 5-methoxy-1-(3,4,5-trimethylphenyl)-1- $\mathrm{H}$-indole, is described as having possible anti-mitotic properties. ${ }^{51}$ Aromatic ethers derived from indole have been synthesized and found useful for the treatment of diseases linked to the dysfunction of $5 \mathrm{HT} 1$-like receptors. ${ }^{52} 5$-hydroxytryptamine $(5 \mathrm{HT})$, commonly called serotonin, is proposed to play an important role in various pathological conditions, such as psychiatric disorders, including anxiety, depression, aggressiveness, panic attacks, obsessive compulsive disorders, schizophrenia, suicidal tendency, and some neurodegenerative disorders, including Alzheimer's disease, Parkinsonism, as well as other health disorders, such as migraine, cephalalgia and those linked to alcoholism. ${ }^{53-58}$ Most of the compounds synthesized are potent agonists of 5HT1-like receptors, and are used for the treatment of migraine and vasospatic disorders. ${ }^{59-64} 3,5$-Substituted indole has been found useful in the control of visceral pain which may be caused by disease or injury to some internal organs. Examples of visceral pains managed by such compounds include inflammatory bowel syndrome, pancreatitis, diverticulitis, Crohn's disease, peritonitis, gastroenteritis, endometriosis, dysmenorrheal interstitial cystitis, dyspepsia, renal colic or biliary colic. ${ }^{65}$ These indole derivatives have not been reported present in any extract of $A$. cissampeloides, but the occurrence of indole in the essential oil may contribute to the use of the plant isolate for the management of nervous disorders in alternative medicine. ${ }^{\text {. }}$

$\gamma$-Elemene has been reported present in appreciable quantity in the leaf essential oil samples of Murraya microphylla and Murraya alata. Caryophyllene, present in the essential oil from A. cissampeloides, is also present in the essential oil of M. microphylla. The essential oil from the two Muraya species have been shown to exhibit antibacterial and antioxidant properties. ${ }^{66}$ Thus, $\gamma$-elemene and caryophllene may contribute to the antibacterial activity of herbal preparations from $A$. cissampeloides. ${ }^{7}$

2,5,5-Trimethyl-1,3,6-hepatriene is an alkene, and has been reported to be a constituent of the essential oil of Salvia bertolonii Vis and Salvia pratensis L. S. pratensis is used as a bactericidal agent for ulcers, wound healing, sore throat, and influenza. ${ }^{67}$

Camphene, a bicyclic monoterpene, is a constituent of many plant essential oils. It is non-toxic and is used as food additive, for artificial flavouring, and in fragrances, as well as in the manufacture of synthetic camphor and insecticides. It has been found to reduce plasma cholesterol and triglycerides in hyperlipidemic rats. ${ }^{68}$ Accumulation of lipids, plasma cholesterol and triglycerides within the blood vessels of the artery is central to the development of atherosclerosis and coronary heart disease ${ }^{69-71}$. In a study, it was found that lipid-lowering therapy is effective in reducing cardiovascular mortality and morbidity in people with peripheral arterial disease, and statin is the recommended drug. ${ }^{72}$ However, some patients do not tolerate statin, while for some, using statin treatment alone does not achieve the desirable lipid level. Thus, there is need to investigate other possible compounds, including those of plant origin, with the same cholesterol-lowering effect. ${ }^{68}$ The hypolipidemic property of the essential oil from Chios mastic gum, MGO, a resin produced by the plant Pistacia lentiscus var. $\mathrm{Chia},{ }^{73}$ was evaluated in rats in which hyperlipidemia was detergent-induced. Treatment of HepG $\longleftarrow 2$ cells with camphene led to a decrease in cellular cholesterol content to the same level as mevinolin, a potential lipid-lowering drug and a well-established 3-hydroxy-3-methylglutaryl coenzyme A (HMG-CoA) reductase inhibitor. The hypolipidemic activity of MGO was unequivocally attributed to camphene, a minor constituent (0.8\%) of the essential oil. However, synergistic action between camphene and other MGO components was observed. Camphene did not exhibit cytotoxicity in human hepatic cells and may be developed as an alternative lipid-lowering agent. ${ }^{68}$ In a study on some plant-derived antioxidants, geraniol and camphene were found to offer significant protection against reactive oxidation species. The results from the study indicated the pharmacological potential of the two compounds in the management of lung inflammatory diseases which arise from oxidative stress. ${ }^{74}$ Camphene $(3.7 \%$ ) was found present in the $1^{\text {st }}$ hour essential oil fraction of $A$. cissampeloides, and may contribute to the observed antihypertensive action of the plant extract in clinical trials ${ }^{11}$ as well as to its use in the management of bronchitis and lung ailments in alternative medicine. ${ }^{8}$

o-Eugenol is one of the terpenoid compounds found to exhibit muscle relaxant, anaesthetic and inhibitory effect on locomotion. Methyl eugenol and cineol also exhibited similar effects..$^{75}$ The sedative effects and motor impairment activity of the root extract of Ferula gummosa have been proposed to be caused by these terpenoid compounds. ${ }^{76}$ Thus, o-eugenol may be responsible for the use of $A$. cissampeloides in the management of stress and nervous disorders. 
$\alpha$-Cubebene is one of the sesquiterpenes derived from the fruit of the Osage tree, Maclura pomifera. In some studies, the constituent sesquiterpenes, singly or in combination, were reported to exhibit excellent repellency against arthropods, such as cockroaches, mosquitoes, mites, ticks, and spiders. ${ }^{77}$ Several of these constituents performed better than the commercial standard N,N-diethyl-3-methylbenzamide (DEET) against female German cockroaches and are contained in a patent. These reports are the basis of a patent on repellents obtained from terpenoids for use against arthropods. ${ }^{78}$ These repellents are less toxic than N,N-diethyl-1,3-methylbenzamide, (DEET), which has been reported to cause severe adverse health effects. ${ }^{79,80}$ $\alpha$-Cubebene may thus increase the insecticidal activity of A. cissampeloides. ${ }^{8}$ This constituent has also been found to be the major constituent in the volatile oil from the peel and flesh of Garcinia mangostana, L. with relative contents of $32 \%$ and $41 \%$, respectively, ${ }^{81}$ and an extract of the plant has been found to offer protective effects against induced cytotoxic changes and increased level of reactive oxygen species, and it has been suggested that the extract may prevent or decrease the severity of Alzheimer disease. ${ }^{82}$ It is possible that $\alpha$-cubebene may contribute to the effectiveness of $A$. cissampeloides in the management of nervous disorders in alternative medicine and may also enhance the insecticidal activity of the plant. ${ }^{8}$

$\beta$-Elemene is present in the $1^{\text {st }}$ and $2^{\text {nd }}$ hour fractions. It is a constituent of Piper nigrum which has been found to exhibit insecticidal activity, and is also employed in alternative medicine in the management of haemorrhoids, cold, congestion, dyspepsia, vomiting, and diarrhea. ${ }^{83}$

Caryophyllene, also known as $\beta$-caryophyllene, is a bicyclic sesquiterpene present in essential oils of many plants and has several medicinal properties. These include anti-inflammatory, anti-carcinogenic, antioxidant, antimicrobial, and analgesic properties. ${ }^{84}$ In a study, $\beta$-caryophyllene was found to increase paclitaxel activity by ten-fold, thus potentiating the anti-cancer activity of paclitaxel on some human tumour lines, suggesting that $\beta$-caryophyllene facilitates the passage of paclitaxel through the cell membrane. ${ }^{85}$ Caryophyllene is present in appreciable quantities in Cannabis sativa (3.8-37.5\%). A cannabis extract, sativex, is used in Canada for the treatment of neuropathic pain in multiple sclerosis, and because $(E)$ - $\beta$-caryophyllene is a significant constituent in cannabis essential oil and shows significant cannabimimetic effects, it is proposed that it may contribute to the overall effect of cannabis medications. Caryophyllene has thus been declared to potentially modulate inflammatory and other pathophysiological processes. ${ }^{86}$ It is also a constituent of essential oils (51.8-57.6 \%) obtained from the dried fruits of Piper guineense ${ }^{87}$ commonly used for the management of mental illness, impotence, hypertension, and as antimicrobial in the practice of alternative medicine in Nigeria ${ }^{88}$, and was also found to exhibit hepatoprotective effect. ${ }^{89}$ Caryophyllene has also been demonstrated to be potentially useful in the prevention and treatment of colitis. ${ }^{90}$ In a study on the anti-tumour properties of the volatile oil from Zanthoxylum rhoifolium Lam leaves and some terpenes including $\beta$-caryophyllene in vitro and in vivo, it was concluded that the volatile oil exhibited efficient anti-tumour activity and significant immunomodulatory action in vivo, which may be attributed to $\beta$-caryophyllene associated to the synergism of other natural compounds present in the volatile oil. ${ }^{91}$ The listed bioactivities of $\beta$-caryophellene may also be expected to be present in preparations of $A$. cissampeloides.

Caryophyllene oxide has been reported to be anti-inflammatory as well as acting as peripheral analgesic, and exhibiting activity against $C$. albicans and repellence against Anopheles gambiae, a malaria vector. ${ }^{92}$ It has also been proposed as a potential therapeutic compound for the prevention and treatment of cancer. ${ }^{93}$ It has been found to exhibit sedative effect on silver catfish. ${ }^{94}$ Studies on Satureja parnassica oil, which is very rich in caryophyllene oxide, has been found to show moderate antibacterial activity against Helicobacter pylori. ${ }^{95}$ Thus, caryophyllene oxide may contribute to the bioactivity of $A$. cissampeloides as an antimicrobial and an analgesic for headache and back pain as claimed in alternative medicine. ${ }^{8}$

4,8,8-Trimethyl-2-methylene-4-vinylbicyclo[5.2.0]nonane has been found to be a constituent (12\%) of the volatile oils from Fusarium trincinctum, an endophytic fungus which showed antimicrobial activity against eight bacteria and two fungi. ${ }^{96}$

2-Isopropyl-5-methyl-9-methylene-bicyclo[4.4.0]dec-1ene is reported present in the essential oil from chocolate mint $(2.75 \%)$, which was observed to possess scavenging $\mathrm{NO}$ radical activity as well as anti-inflammatory activity. ${ }^{97}$

Alloaromadendrene and caryophyllene, both present in the essential oils from $A$. cissampeloides have been found present in the essential oil from the leaves of Psidium guajava, ${ }^{98}$ which have been reported to exhibit antibacterial property and were efficacious in the management of diarrhea, dysentery, and gastroenteritis. ${ }^{99}$

Geranyl acetone has been reported present in the leaf essential oil obtained from $S$. radiatum, a pro-fertility medicinal plant ${ }^{2}$, and also in the rhizome of two types of Curcuma longa grown in Bangladesh and used in the management of jaundice, liver ailments, ulcers, parasitic infections, and skin diseases. ${ }^{100}$ The compound has also been reported as a constituent of volatile organic compounds in normal skin area in a study on analytical profiling of chronic wounds. ${ }^{101}$

$\alpha$-Humulene has been isolated from the essential oil of Cordia verbenacea and was found to produce anti-inflammatory effects comparable to those observed in dexamethasone-treated animals. ${ }^{102}$ This constituent may be useful in the management of pain arising from inflammation, and may be responsible for this bioactivity of $A$. cissampeloides.

$\alpha$-Amorphene, a sesquiterpene, and some other constituents in the essential oil from $A$. cissampeloides, including $\alpha$-terpineol, camphene, $\beta$-elemene, caryophyllene, $\alpha$-humulene, $\gamma$-muurolene, $\delta$-cadinene $(-)$-spathulenol, and caryophyllene oxide have been reported present in the flower essential oil of Magnolia liliflora, which has been found effective in the management of decubitus ulcer in nursing pregnant women. ${ }^{103}$ It is possible that the leaf essential oil from $A$. cissampeloides may exhibit such bioactivity. This finding is relevant to the use of preparations from $A$. cissampeloides in the treatment of wounds and sores. 
$\gamma$-Muurolene, a sesquiterpene, and other constituents, namely, terpinen-4-ol, $\beta$-elemene, $\alpha$-amorphene, $\delta$-cadinene, and $n$-hexadecanoic acid, all present in the essential oil from $A$. cissampeloides, have been reported present in the essential oil obtained from Radix Linderae, which has been found useful in preventing the occurrence of decubitus in aged people. ${ }^{104}$ This observation may lead to the expectation that $A$. cissampeloides and $R$. Linderae essential oils may have some bioactivities in common.

Germacrene D, an anti-mosquito compound, ${ }^{105}$ has been found present in the ethanol extracts of the leaves of Vitex negundo L. Other compounds present in the extract, which are also present in the essential oils from $A$. cissampeloides, include $\beta$-elemene, caryophyllene oxide, $(+)$-spathulenol, $\alpha$-linolenic acid, $n$-hexadecanoic acid, phytol, and octadecanoic acid. The ethanol leaf extract of $V$. negundo was observed to possess remarkable larvicidal, oviposition deterrent and repellent activity against hazardous mosquitoes, namely Aedes aegypti, Anopheles stephensi, and Culex quinquefasciatus. ${ }^{106}$ Thus, some bioactivities, especially repellence activity may be observed in $A$. cissampeloides.

$\beta$-lonone is a constituent of a formulation for exterminating lice and lice eggs. The formulation consists of one or more terpenes, namely, limonene, $\beta$-ionone, linalool, geraniol, myrcene, and carvone. $\beta$-lonone has antibacterial and antifungal properties. ${ }^{107}$ Thus, the essential oil form $A$. cissampeloides may be expected to exhibit antimicrobial activity as well as these insecticidal properties.

Bicyclogermacrene has been reported present in the essential oil from the fresh leaves of Piper cernuum and Piper regnellii. Other constituents present in both $P$. regnellii and essential oils from the leaves of $A$. cissampeloides include linalool, $\alpha$-terpineol, $\beta$-caryophyllene, $\alpha$-humulene, spathulenol, and caryophyllene oxide. The essential oils obtained from $P$. cernuum and $P$. regnellii were observed to display significant activities against Staphylococcus aureus and Candida albicans. ${ }^{108}$ This antimicrobial activity may be expected to be observed in the essential oils from A. cissampeloides.

$\delta$-Cadinene is present in all the fractions. It has been identified as one of the major components in the essential oil from the peel of orange fruit, Citrus sinensis. The essential oil of C. sinensis exhibited antimicrobial activity against some Gram-positive and Gram-negative bacteria as well as Candida strains. ${ }^{109}$

$(+)$ - and (-)-spathulenol, $\beta$-caryophyllene, and caryophyllene oxide, all present in the essential oils of $A$. cissampeloides, have also been reported present in the leaf essential oil of Stevia rebaudiana, and these constituents have been demonstrated to partially account for the antimicrobial activity of the aqueous leaf extract of $S$. rebaudiana. ${ }^{110}$ Extracts from the plant have been found to act as a hypotensive regulator and also observed to possess hypoglycemic, antimicrobial, and contraceptive activities. Caryophyllene oxide and spathulenol constituted $43 \%$ of essential oil from leaves of $S$. rebaudiana from Brazil. ${ }^{111}$ These two constituents identified in Salvia sclarea oil were found to be active against $S$. aureus. ${ }^{112}$ The essential oil obtained from Salvia elegans Vahl, was found to contain spathulenol and caryophyllene as the major components, and was reported to exhibit excellent inhibitory larvicidal effect against Aedes albopictus, a mosquito vector. ${ }^{113}$ This bioactivity may be exhibited by $A$. cissampeloides.

(+)-Spathulenol, (-)-guaiol, and caryophyllene oxide were the isolated compounds from the essential oil of Aloysia gratissima responsible for anaesthetic induction in silver catfish. Spathulenol showed potent sedative and anaesthetic activities in silver catfish, and was proposed as a viable compound for the development of a new anaesthetic. $^{94}$

Guaiol has been found present in the essential oil of Teucrium polium L. and was reported to inhibit the intestinal motility of the isolated rabbit jejunum. Crystalline isolation and physicochemical characterization has identified guaiol as a major constituent of an active spasmolytic fraction of the essential oil of T. polium L. ${ }^{114}$ Guaiol was found to exhibit sedative effect on silver catfish. ${ }^{94}$ Thus, the essential oil from A. cissampeloides leaves may exhibit anaesthetic effect.

$\alpha$-Gurjunene and elemol both present in the essential oil from $A$. cissampeloides have been found present in the volatile components in Rhizome Zingibers, Zingiber Officinale Roscoe, and Ginger Pee which are used in Chinese traditional medicine for rheumatism, cold, stomach pain, and diarrhea. ${ }^{115}$

Benzyl benzoate emulsion was reported in 1946 as a very effective miticide in the management of scabies, and when incorporated at $68 \% \mathrm{v} / \mathrm{v}$ into a mixture of dichlorodiphenyltrichloroethane, DDT (6 \%), benzocaine (12\%), and Tween 80 (14\%), was found to be miticidal, larvicidal, lousicidal, ovicidal and antipruritic. DDT is ineffective against human scabies. ${ }^{116}$ This constituent may contribute to the effectiveness of the leaves of $A$. cissampeloides in the management of scabies.

Cis,cis,cis-7,10,13-Hexadecatrienal is one of the major constituents in the methanol leaf extract of Lantana camara, which was found to have larvicidal effect on some species of mosquitoes. Other constituents present in the extract, which are also found in the essential oils from $A$. cissampeloides, include oleic acid, hexadecanoic acid, and phytol. ${ }^{117} n$-Hexadecanoic acid, present in the essential oils from both plants, has been reported as a potent mosquito larvicide. ${ }^{118}$ Thus, the essential oils from the leaves of $A$. cissampeloides may function as a mosquito larvicide.

Hexahydrofarnesyl acetone is present in all the hourly fractions as well the 4-hour sample. It has been reported present in appreciable concentration in the essential oil obtained from the leaves of C. procera (Ait.) R. Br. The insecticidal potential and possible role in malaria control was discussed. ${ }^{5}$ It is the oxidation product of phytol ${ }^{119}$ and some of this constituent may actually be present as phytol in the native plant material prior to hydrodistillation.

Cis,cis-7,10-Hexadecadienal has been reported present as one of the major constituents in the essential oil obtained from the leaves and stem of Euphorbia heterophylla, a medicinal plant used traditionally in the management of gonorrhoea, respiratory tract infection, and warts, and found 
effective as a fish poison and insecticide. It has also been shown to exhibit some antimicrobial and anti-inflammatory properties. Other constituents common to the essential oils of $E$. heterophylla and $A$. cissampeloides include linoleic acid, phytol, oleic acid, and octadecanoic acid. ${ }^{120}$

Isophytol has been reported to be very toxic to aquatic life with very long lasting effects, and is suspected of damaging fertility or human foetus. It is also reported to irritate the eyes, skin, and respiratory system. ${ }^{121}$ Isophytol in the essential oil may be an abortifacient.

Phytol has been found present in some medicinal plants used in the management of asthma in alternative medicine. These include essential oils from the leaves of C. procera ${ }^{5}$ and E. hirta. ${ }^{4}$ The anti-inflammatory property of phytol as well as its reactive oxygen species-promoting property and its bioactivity in long suppression of arthritis ${ }^{6}$ was suggested as being responsible for the possible response of asthmatic patients when these extracts are employed in alternative medicine. The appreciable quantity of phytol in the essential oil of $A$. cissampeloides may be suggestive of a possible role of the plant in the effective management of arthritis and asthma. Phytol has been identified as a major component in the ethyl acetate-soluble fraction obtained from the methanolic extract of the leaves of Pereskia bleo, a medicinal plant alleged to have anti-cancer, anti-tumour, anti-rheumatic, anti-ulcer, and anti-inflammatory properties. It is also used for the relief of gastric pain. In a study of the cytotoxic activity of the plant ${ }^{122}$, it was found that the ethyl acetate fraction exhibited high cytotoxic activity against human nasopharyngeal epidermoid carcinoma cell line and lower toxicity against human colon carcinoma cell line and hormone-dependent breast carcinoma cell line. It was proposed by the authors that phyto1, which has been found to show significant anti-tumour activity against mouse lymphocytes leukaemia cells, lymphoid leukaemia cells, human colon cancer cells, and gastric cancer cells, was responsible for the reported bioactivity of the plant. This suggests that the essential oils from $A$. cissampeloides may exhibit some anti-cancer and anti-tumour activity due to the presence of phytol. Phytol has also been reported to be a tumour promoter on I CR mouse skin. ${ }^{123}$ Phytol and derivatives are the subject of a patent claiming that these compounds can serve as active ingredients in medicaments to lower serum levels of triglycerides and/or cholesterol, and can be administered to patients with disease conditions, such as type II diabetes, obesity or patients with cardiovascular disease. ${ }^{124}$ These findings may also explain the anti-hypertensive activity of $A$. cissampeloides, and suggest the usefulness of the plant in the management of type II diabetes and obesity.

The essential oils contain five kaurene derivatives, namely, kaurene-15-ene, kaurene-16-ene, kaurene, kauran-16-ol, and 16 .ß. H-kauran-16-ol. Kaurane diterpenes, including (-)-ent-kaur-16-en-19-oic acid, (-)-kaur-16-en-19-ol, and (-)-kauran-16- $\alpha$-o1, have been reported to be effective against trypomestigotes of Trypanosome cruzi, a parasitic protozoan capable of causing life-threatening infections and cardiac complications. ${ }^{125}$ Natural stevioside has a kaurene skeleton as aglycone. It has been shown that it can lower blood sugar ${ }^{126}$ and blood pressure. ${ }^{127}$ In animal studies, it has been shown to be a diuretic and was also found to stimulate the secretion of insulin. ${ }^{128}$ Medicaments incorporating kaurene structure have been patented for the treatment of non-insulin dependent diabetes mellitus and hypertension ${ }^{129}$, and also for treating and preventing coronary heart disease, cerebral apoplexy, cerebral ischemia, and rhythm disturbance. ${ }^{130}$ These reports suggest possible medicinal applications of $A$. cissampeloides.

The saturated fatty acids in the essential oils are pentadecanoic acid, $n$-hexadecanoic acid, and octadecanoic acid, while the unsaturated fatty acids are $\alpha$-linolenic acid, linoleic acid, and oleic acid. $n$-Hexadecanoic acid and $\alpha$-linolenic acid are present in appreciable quantities compared to the other fatty acids. Fatty acids are reported to exhibit antibacterial and antifungal properties. ${ }^{131,132} n$-Hexadecanoic acid inhibits phospholipase A2 which hydrolyses ester bonds and initiates steps resulting in inflammation which can lead to pathological conditions of rheumatoid arthritis, bronchial asthma, ulcerative colitis, psoriasis, and Crohn's disease. ${ }^{133}$ The anti-inflammatory property of $n$-hexadecanoic acid, including structural evidence and kinetic measurements, has been reported ${ }^{133}$ and the authors proposed that the results validate the rigorous use of oils rich in hexadecanoic acid for the treatment of rheumatic systems. This fatty acid is also reported to be hypocholesterolemic, nematicidal, pesticidal, and functions as an antioxidant, anti-androgenic flavour and 5 - $\alpha$-reductase inhibitor ${ }^{134}$ and a potent mosquito larvicide. ${ }^{118}$ Octadecanoic acid exhibits antimicrobial activity. ${ }^{118}$ Linoleic acid methyl ester exhibits anti-cancer activity. ${ }^{135}$ Oleic acid exhibits antibacterial activity $^{136}$, while $\alpha$-linolenic acid exhibits higher anti-inflammatory activity than docosahexaenoic acid. ${ }^{137}$ The occurrence of these fatty acids in the essential oils from A. cissampeloides may render the plant effective in the management of diseases which arise from inflammation; these include bronchial asthma and arthritis. These fatty acids also support the antimicrobial activity of the plant, and suggest its potential as anti-cancer agent and mosquito larvicide.

Analysis of the hourly fractions of the essential oils revealed the occurrence of some constituents that were not detected in the conventional 4-hour collection. These results are a guide to the fractions that are rich in certain constituents. For example, azulene, caryophellene, and phytol are found largely in the 4-hour collection, while (-)-myrtenol, camphene, $\beta$-elemene, and $\alpha$-humulene are predominant in the first hour fraction.

\section{Conclusion}

The results from this study show that several constituents of the essential oils have potentials as medicaments in the management of hypertension, nervous disorders, headache, pain, and leprosy. Insecticidal potential is also proposed. Some of the constituents, such as phytol, (13S)8,13-epoxy-labd-14-ene, $n$-hexadecanoic acid, 1,13-tridecanediol diacetate, $\alpha$-gurjunene, and germacrene $D$ can be isolated from the essential oils and their bioactivities investigated. The effects of climate, soil, drying conditions, and methods of isolation of the essential oils on the constituents should also be investigated. 


\section{ACKNOWLEDGEMENTS}

The authors express appreciation to Mr. S. K. Odewo for his advice on plant selection and authentication, Mrs. J. O. Olafimihan, Chief technologist, Mr. Dan Achem and Mr. Mejida, technologists of the University Central Research Laboratory for assistance with the GC-MS, and to the University of Lagos for the facilities and reagents.

\section{References}

1. T. Odugbemi. The Diversity of Uses of Medicinal Plants in Nigeria, in T. Odugbemi (Ed.), A Textbook of Medicinal Plants from Nigeria, University of Lagos Press, Lagos, Nigeria, 2008 pp. 71-79.

2. M. Ogunlesi, W. Okiei, E. A. Osibote, Analysis of the essential oil from the leaves of Sesamum radiatum, a potential medication for male infertility factor, by gas chromatography-mass spectrometry, Afr. J. Biotechnol. 9 (2010) 1060-1067, doi: https://doi.org/10.5897/AJB09.941.

3. E. Osibote, N. Noah, Sadik O. Noah, D. McGee, M. Ogunlesi, Electrochemical sensors, MTT and immunofluorescence assays for monitoring the proliferation effects of Cissus populnea extracts on Sertoli cell, Reprod. Biol. Endocrinol. 9 (2011) 65, doi: https://doi.org/10.1186/1477-7827-9-65.

4. M. Ogunlesi, W. Okiei, E. Ofor, A. Osibote, Analysis of the essential oil from the dried leaves of Euphorbia hirta Linn (Euphorbiaceae), a potential medication for asthma, Afr. J. Biotechnol. 8 (2009) 7042-7050, doi: https://doi.org/10.5897/ AJB09.1324.

5. W. Okiei, M. Ogunlesi, E. Ofor, E.A.S. Osibote, Analysis of essential oil Constituents in hydro-distillates of Calotropis procera (Ait.) R. Br, Res. J. Phytochem. 3 (2009) 44-53, doi: https://doi.org/10.3923/rjphyto.2009.44.53.

6. M. Hultqvist, P. Olofsson, K. A. Gelderman, J. R Holmdahl, A new arthritis therapy with oxidative burst inducers, Plos. Med. 3 (2006) 1-17, doi: https://doi.org/10.1371/journal. pmed.0030348.

7. T. Odugbemi, A Textbook of Medicinal Plants from Nigeria, University of Lagos Press, Lagos, Nigeria, 2008, p. 543.

8. O. M. Grace, D. G. Fowler, Adenia cissampeloides (Planch. Ex Hook), (2007), Harms. [Internet] Record from PROTA4U, in G.H. Schmelzer, A. Gurib-Fakim, (Eds.), PROTA (Plant Resources of Tropical Africa / Ressources végétales de l'Afrique tropicale), Wageningen, Netherlands, http://database.prota. org/search.htm.

9. O. V. Njoku, C. Obi, Phytochemical constituents of some selected medicinal plants, Afr. J. Pure Appl. Chem. 3 (2009) 228-233, http://www.academicjournals.org/ajpac.

10. F. N. I. Morah, Tetraphyllin B from Adenia cissampeloide, Phytochem. 27 (1988) 2985-2986, doi: https://doi. org/10.1016/0031-9422(88)80704-0.

11. A. A. Nyarko, M. E. Addy, Effects of aqueous extract of Adenia cissampeloides on blood pressure and serum analyte of hypertensive patients, Phytother. Res. 4 (1990) 25-28, doi: https://doi.org/10.1002/ptr.2650040107.

12. O. O. Akinkugbe, G. D. Nicholson, J. K. Cruickshank, Heart disease in blacks of Africa and the Caribbean, Cardiovasc. Clin. 21 (1991) 377-391, url: https://www.ncbi.nlm.nih.gov/ pubmed/2044116.

13. R. Cooper, C. Rotimi, S. Ataman, D. McGee, B. Osotimehin, S. Kadiri, W. Muna, S. Kingue, H. Fraser, T. Forrester, F. Bennett, $R$. Wilks, The prevalence of hypertension in seven populations of West Africa origin, Am. J. Public Health 87 (1997) 160-168, doi: https://doi.org/10.2105/AJPH.87.2.160.
14. S. D. Pierdomenico, M. Di Nicola, A. L. Esposito, R. Di Mascio, E. Ballone, D. Lapenna, F. Cuccurullo, Prognostic value of different indices of blood pressure variability in hypertensive patients, Am. J. Hypertens. 22 (2009) 842-847, doi: https:// doi.org/10.1038/ajh.2009.103.

15. D. A. Calhoun, D. Jones S. Textor, D. C. Goff, T. P. Murphy, R. D. Toto, A. White, W. C. Cushman, W. White, D. Sica, K. Ferdinand, T. D. Giles, B. Falkner, R. M. Carey, Resistant hypertension: diagnosis, evaluation and treatment. A scientific statement from the American Heart Association Professional Education Committee of the Council for High Blood Pressure Research. Hypertens. 51 (2008) 1403-1419, doi: https://doi.org/10.1161/HYPERTENSIONAHA.108.189141.

16. R. Garcia, E. S. S. Alves, M. P. Santos, G. M. F. V. Aquije, A. A. R. Fernandes, R. B. dos Santos, J. A. Ventura, P. M. B. Fernandes, Antimicrobial activity and potential use of monoterpenes as tropical fruits preservatives, Braz. J. Microbiol. 39 (2008) 163-168, doi: https://doi.org/10.1590/S1517838220080001000032

17. B. Riedl, R. Endermann, Recent developments with oxazolodinone antibiotics, Expert Opin. Ther. Pat. 9 (2005) 625633, doi: https://doi.org/10.1517/13543776.9.5.625.

18. C. W. Ford, J. C. Hamel, D. Stapert, J. K. Meerman, D. K. Hutchinson, M. R. Barbachyr, G. E. Zurenko, Oxazolidinones: New bacterial agents, Trends Microbiol. 5 (1997) 196-200, doi: https://doi.org/10.10016/S0966-842X(97)01032-9.

19. Y. Fukuda, M. Hammond (Kyorin Pharmaceutical Co. Ltd, Merck and Co. Inc.) USPTO Appl. 20050203144A1, 15 Sept 2005. Bicyclo [3.1.0.] hexane containing oxazolidinone antibiotics and derivatives thereof. Publication Date: March 12, 2009.

20. A. S. Basile, A. Janowsky, K. Golembiowska, M. Kowaliska, E. Tam, M. Benvenitse, R. Popik, A. Nikiforuk, Characteristics of the antinociceptive actions of bicifadine in models of acute, persistent and chronic pain, J. Pharmacol. Exp. Ther. 321 (2007) 1208-1225, doi: https://doi.org/10.1124/ jpet.106.116483.

21. P. Skolnick, P. Popik, A. Janowsky, B. Beer, A. S. Lippo, Antidepressant-like actions of DOV 21, 947: A "triple" reuptake inhibitor. Eur. J. Pharmacol. 461 (2003) 90-104, doi: https:// doi.org/10.1016/S0014-2999(03)01310-4.

22. L. Arista, G. Bonanomi, A. M. Capelli, F. Damiani, D. G. Gentile, D. Hamprecht, F. Micheli, L. Tarsi, G. Tedesco, S.Terreni, (Glaxo Group Ltd) Eur. Pat. Appl. 2070922B117 Aug 2011; Azabicyclo [3.1.0.] hexane derivatives useful as modulators of dopamine D3 receptors, https://patents.google.com/patent/EP2070922B1/en (12. 3. 2018).

23. P. Skolnick, P. Krieter, J. Tizzanno, A. Basile, P. Popik, P. Czobor, A. Lippa, Preclinical and clinical pharmacology of DOV 216,303, a "triple" reuptake inhibitor, CNS Drug Reviews Summer: 12 (2006) 123-134, doi: https://doi.org/10.1111/ j.1527-3458.2006.00123.X.

24. M. Briley, Clinical experience with dual action antidepressants in different chronic pain syndromes, Hum Psychopharmacol. Clin. Exp. 19 (2004) S21-S25, doi: https://doi. org/10.1002/hup.621.

25. R. D. Shytle, A. A. Silver, R. J. Lukas, M. B. Newman, D. V. Sheehan, P. R. Sanberg, Nicotinic acetylcholine receptors as targets for antidepressant, Mol. Psychiatry 7 (2002) 525535, doi: https://doi.org/10.1038/sj/mp.4001035.

26. R. D. Shytle, A. A. Silver, K. H. Sheehan, D. V. Sheehan, P. R. Sandberg, Neuronal nicotinic receptor inhibition for treating mood disorders: preliminary controlled evidence with mecamylamine, Depression and Anxiety 16 (2002) 89-92, doi: https://doi.org/10.1002/da.10035.

27. M. J. O’Neill, T. K. Murray, V. Kakics, N. P. Visanji, S. Duty, The role of neuronal nicotinic acetylcholine receptors in 
acute and chronic neurodegeneration, CNS Neurol. Disord. Drug Targets 1 (2002) 399-411, doi: https://doi. org/10.2174/1568007023339166.

28. E. D. Levin, A. H. Rezvani, Nicotinic treatment for cognitive dysfunction, CNS Neurol. Disord. Drug Targets 1 (2002) 423431, doi: https://doi.org/10.2174/1568007023339102.

29. J. P. McEvoy, T. B. Allen, The importance of nicotinic acetylcholine receptors in schizophrenia, bipolar disorder and Tourette's syndrome. CNS Neurol. Disord. Drug Targets 1 (2002) 433-442, doi: https://doi. org/10.2174/1568007023339210.

30. M. R. V. Santos, F. V. Moreira, B. P. Fraga, D. P. De Sousa, L. R. Bonjardim, L. J. Quintans-Junior, Cardiovascular effects of monoterpenes: a review, Rev. Bras. Farmacogn. 21 (2011) 764-771, doi: https://doi.org/10.1590/S0102695X2011005000119.

31. M. Höferl, S. Krist, G. Buchbauer, Chirality influences the effects of linalool on physiological parameters of stress, Planta Med. 72 (2006) 1188-1192, doi: https://doi. org/10.1055/s-2006-947202.

32. J. A. C. Menezes, C. M. N. Barreto, A. R. Antoniolli, M. R. V. Santos, D. P. De Sousa, Hypotensive activity of terpenes found in essential oils, Z. Naturforsch C. 65 (2010) 562-566, doi: https://doi.org/10.1515/znc-2010-9-1005.

33. W. F. Hink, T. E. Duffey (Shirlo Inc), US Pat. Appl. 4933371A, 6. Dec. 1990. Controlling ticks and fleas with linalool, URL: http://www.google.com/patents/US4933371 (13. 3. 2018).

34. R. N. Sharma, K. N. Saxena, Orientation and development inhibition in the housefly by certain Terpenoids, J. Med. Entomol. 11 (1974) 617-621, cited in R. Waliwitiya, C. J. Kennedy, C. A. Lowenberger, Larvicidal and oviposition-altering activity of monoterpenoids, trans-anithole and rosemary oil to the yellow fever mosquito Aedes aegypti (Diptera: Culicidae), Pest Manag. Sci. 65 (2009) 241-248, doi: https://doi. org/10.1002/ps.1675.

35. A. Q. G. Zhifeng, GC-MS Analysis of Volatile Compounds in Thea vivrdis, green tea. Journal of Hebei University (Natural Sciences Ed.): 1997-03 (1997) Baoding 071002, doi: https://doi.org/en.cnki.com.cn/Article_en/CJFDTOTAL-HBDD703.006.htm.

36. A. A. Shareef, Evaluation of antibacterial activity of essential oils of Cinnamomum sp. and Boswellia sp., Journal of Basrah Researches (Sciences) 37 (5.A) (2011).

37. F. Mondello, F. De Bernardis, A. Girolamo, A. Cassone, G. Salvatore, In vivo activity of terpinen-4-ol, the main bioactive component of Melaleuca alternifolia Cheel (tea tree) oil against azole- susceptible and -resistant human pathogenic Candida species, BMC Infect. Dis. 6 (2006) 158, doi: https:// doi.org/10.1186/1471-2334/6/158.

38. F. Mondello, A. Girolamo, M. Scaturro, M. L. Ricci, Determination of Legionalla pneumophila susceptibility to Melaleuca alternifolia Cheel (tea tree) oil by an improved broth micro-dilution method under vapour controlled conditions, J. Microbiol. Method 77 (2009) 243-248, doi: https://doi. org/10.1016/j.mimet.2009.02.012.

39. F. Mondello, M. L. Ricci, (Istituto Superiore Di Sanita), Pub. No. WO2012014244A1, Appl. No. PCT/IT2011/000267, 2 Feb 2012. Use of Terpinen-4-ol as Antimicrobial Agent against Bacteria of Legionella Genus, URL: http://www.google.com/patents/WO2012014244A1?cl=en (14. 3. 2018).

40. S. F. Lahlou, A. F. Figueiredo, P. J. Magalhães, J. H. Leal-Cardoso, Cardiovascular effects of 1, 8-cineole, a terpenoid oxide present in many plant essential oils, in normotensive rats, Can. J. Physiol. Pharmacol. 80 (2002) 1125-1131, doi: https://doi.org/10.1139/Y02-142.

41. S. Lahlou, L. F. Interaminense, J. H. Leal-Cardoso, G. P. Du- arte, Antihypertensive effects of the essential oil of Alpinia zerumbet and its main constituent, terpinen-4-ol in DOCA-salt hypertensive conscious rats, Fundam. Clin. Pharmacol. 17 (2003) 323-330, doi: https://doi.org/10:1046/ j.1472-8206.2003.00150x.

42. F. A. Andersen, Final Report on the Safety Assessment of Azulene, Int. J. Toxicol. 18 (Suppl. 3) (1999) 27-32, doi: https:// doi.org/10.1177/109158189901800304.

43. M. Ramadan, S. Goeters, B. Watzer, E. Krause, K. Lohmann, R. Bauer, H. Hempel, P. J. Imming, Chamazulene carboxylic acid and matricin: a natural profen and its natural prodrug identified through similarity to synthetic drug substance, J. Nat. Prod. 69 (2006) 1041-1045, doi: https://doi.org/10.1021/ np0601556.

44. K. Saito, T. Okabe, Y. Ihamori, H. Tsujibo, Y. Miyaka, K. Hiraoka, N. Ishida, The biological effects of monoterpenes: Hypotensive effects on rats and antifungal activities on plant pathogenic fungi of monoterpenes, Mokuzai Gakkaishi 42 (1996) 677-680, cited in M.R.V. Santo et al., (2011), ref. 30.

45. P. J. Magalhães, J. S. Lahlou, D. M. Jucá, L. M. Coelho-De Souza, P. T. Da Frota, A. M. Da Costa, J. H. Leal-Cardoso, Vasorelaxation induced by essential oil in Croton nepetaefolius and its constituents in rat aorta are partially mediated by the endothelium, Fundam. Clin. Pharmacol. 22 (2008) 169-177, doi: https://doi.org/10.1111/j.1472-8206.2008.00571x.

46. T. P. Ribiero, D. L. Porto, L. P. Menezes, A. A. Antunes, D. F. Silva, D. P. De Sousa, L. S. Nakao, V. A. Braga, I. A. Medeiros, Unravelling the cardiovascular effects induced by $\alpha$-terpineol. A role for the nitric oxide-cGMP pathway, Clin. Exp. Pharmacol. Physiol. 37 (2010) 811-816, doi: https://doi. org/10.1111/j.1440-1681.2010.05383.x.

47. B. Prakash, P. Singh, R. Goni, A. Raina, N. Dubey, Efficacy of Angelica archangelica essential oil, phenyl ethyl alcohol and alpha-terpineol against isolated molds from walnut and their antiflatoxigenic and antioxidant activity, J. Food Sci. Technol. 52 (2015) 2220-2228, doi: https://doi.org/10.1007/s13197014-1278-X.

48. C. L. Zhang, Y. F. Liu, Y. Wang, D. Liang, Z. B. Jiang, L. Li, Z.-Y. Hao, H. Luo, G.-R. Shi, R.-Y. Chen, Z.-Y. Cao, D.-Q. Yu, Polycycloiridals A-D, four Iridial-type triterpenoids with an alpha-terpineol moiety from Iris tectorum, Org. Lett. 17 (2015) 5686-5689, doi: https://doi.org/10.1021/acs.orglett.5b02982.

49. L. Li, V. Martins, Synthesis of substituted indoles via a highly selective 7-lithiation of 4,7-dibromoindoles and the effect of indole-nitrogen on regioselectivity, Tetrahedron Lett. 44 (2003) 5987-5990, doi: https://doi.org/10.1016/S00404039(03)01482-5.

50. H. Fuwa, M. Sasaki, Synthesis of 2-substituted indoles and indolines via Suzuki-Miyaura coupling/5-endo-trig cyclization strategies, J. Org. Chem. 74 (2009) 212-221, doi: https:// doi.org/10.1021/jo801985a.

51. T. B. Monroe, C. Rimland, Y. Moazami, D. S. Jones, C.A. Ogle, 5-Methoxy-1-(3, 4, 5-trimethoxyphenyl)-1H-indole, Acta Cryst. E6 (2010) o1678, doi: https://doi.org/10.1107/ S1600536810018568.

52. M. Perez, S. Halazy, J. Gareth, J.-P. Valentin, P. Pauwels, (Pierre Fabre Medicament SA), US Pat. Appl. 5852049, 22 Dec 1998, Aromatic ethers derived from indole which are useful as medicaments, URL: https://www.google.ch/patents/ US5852049 (14. 3. 2018).

53. E. Zifa, G. Fillion, 5-Hydroxytryptamine receptors. Pharm. Reviews 44 (1992) 401-458, cited in Perez et al. (1998), ref. 52.

54. A. Mouligner, Central serotonin receptors. Principal fundamental and functional aspects, Therapeutic applications, Rev. Neuro. (Paris) 150 (1994) 3-15, cited in Perez et al. 
(1998), ref. 52.

55. S. Langer, N. Brunello, G. Racagni, J. Mendelwicz, (1992). Serotonin receptors subtypes: pharmacological significance and clinical implications, Karger (ed.), cited in Perez et al. (1998), ref. 52.

56. B. E. Leonard, Sub-types of serotonin receptors: biochemical changes and pharmacological consequences, Int. Clin. Psychopharmacol. 7 (1992) 13-21, doi: https://doi. org/10.1097/00004850-199200710-00002.

57. D. G. Graham-Smith, Int. Clin. Psychopharmacology, 6 (Suppl. 4) (1992) 6-13, cited in Perez et al., (1998), ref. 52.

58. R. W. Fuller, Basic advances in serotonin pharmacology, J. Clin. Psychiatry 53 (1992) Suppl: 36-45, URL: http://www. ncbi.nlm.nih.gov/pubmed/1429483. (14.3.2018)

59. A. Doenicke, J. Brand, M. J. Perrin, Possible benefit of GR43175, a novel 5HT1-like receptor agonist for the acute treatment of migraine, The Lancet 331 (8598) (1988) 13091311, doi: https://doi.org/10.1016/S0140-6736(88)921228

60. M. D. Ferrari, P. R. Saxena, On serotonin and migraine: a clinical and pharmacological review, Cephalagia 13 (1993) 151-165, doi: https://doi.org/10.1046/j.14682982.1993.1303151.x

61. S. J. Peroutka, The pharmacology of current antimigraine drugs, Headache: The Journal of Head and Face Pain 30 (1990) 5-11, doi: https://doi.org/10.1111/j.1526-4610.1990. hed30s1005.x.

62. M. A. Moskowitz, Neurogenic versus vascular mechanism of sumatripan and ergot alkaloids in migraine, Trends Pharmacol. Sci. 13 (1992) 307-311, doi: https://doi. org/10.1016/0165-6147(92)90097-P.

63. W. Feniuk, P. P. Humphrey, M. J. Perren, H. E. Connor, E. T. Whalley, Rational for the use of 5-HT ${ }_{1}$-like agonists in the treatment of migraine, J. Neurol. 238 (Suppl. 1) (1991) S57S61, doi: https://doi.org/10.1007/BF01642908.

64. V. Anastasia, B. S. Deliganis, S. J. Peroutka, 5-Hydroxtryptamine 1D Receptor Agonism Predicts Antimigraine Efficacy, Headache 31 (1991) 228-231, doi: https://doi. org/10.1111/j.1526-4610.1991.hed3104228.x, cited in Perez et al., (1998), ref. 52.

65. S. Maddaford, J. Ramnauth, S. Rakhit, J. Patman, P. Renton, S. C. Annedi, J. S. Andrews, J. Mladenova (Neuraxon. Inc.), WO. Pat. Appl. 2009062319A1, 22 May 2009. Indole compounds and methods for treating visceral pain, URL: http:// www.google.com/patents/WO2009062319A1?cl=en $\quad(14$. 3. 2018).

66. Y.-S. Huang, K. Yuan, Y. Bai, Chemical composition, antimicrobial and antioxidant activities of the essential oils of Murraya microphylla and Murraya alata, Res. J. Chem. Environ. 17 (4-6) (2013) 34-40, doi: https://doi.org/10.3184/174751 912X13547276507240.

67. G. Anackov, B. Bozin, L. Zoric, D. Vukov, N. Mimica-Dunkic, L. Merkulov, R. Igic, M. Jovanovic, P. Boza, Chemical composition of essential oil and leaf anatomy of Salvia bertolonii Vis. and Salvia pratensis L. (Sect. Plethiosphace, Lamiaceae), Molecules 14 (2009) 1-9, doi: https://doi.org/10.3390/molecules14010001.

68. I. Vallianou, N. Peroulis, P. Pantazis, M. Hadzopoulou-Cladaras, Camphene, a plant-derived monoterpene reduces plasma cholesterol and triglycerides in hyperlipidemic rats independently of HMG-CoA reductase activity, Plos One 6 (2011):e20516, doi: https://doi.org/10.1371/journal. pone.0020516

69. K. M. Anderson, P. W. Wilson, R. J. Garrison, W. P. Castelli, Longitudinal and secular trends in lipoprotein cholesterol measurements in a general population sample, The Framing- ham Offspring Study, Atherosclerosis 68 (1987) 59-66, doi: https://doi.org/10.1016/0021-9150(87)90094-3.

70. S. M. Grundy, Treatment of hypercholesterolemia, Am. J. Clin. Nutr. 30 (1977) 985-992, doi: https://doi.org/10.1093/ ajcn/30.6.985.

71. Expert Panel. Third Report of the National Cholesterol Education Program (NCEP). Expert Panel on Detection, Evaluation and Treatment of High Blood Cholesterol in Adults. (Adult Treatment Panel III) Final Report: Circulation 106 (2002) 3143-3421, url: https://www.ncbi.nlm.nih.gov/pubmed/12485966 (15. 3. 2018).

72. P. P. Aung, H. G. Maxwell, R. G. Jepson, J. F. Price, G. C. Leng, Lipid-lowering for peripheral arterial disease of the lower limb, Conchrane Database Syst. Rev. 17 (2007) CD000123, doi: https://doi.org/10.1002/14651858.CD000123.pub2.

73. P. Magiatis, E. Melliou, A. L. Skaltsounis, I. B. Chinou, S. Mitaku, Chemical composition and antimicrobial activity of the essential oils of Pistacia lentiscus var. Chia, Planta Med. 65 (1999) 749-752, doi: https://doi.org/10.1055/S-2006-960856.

74. M. Tiwari, P. Kakkar, Plant derived antioxidants- Geraniol and camphene protect rat alveolar macrophages against t-BHP induced oxidation stress, Toxicol. In Vitro 23 (2009) 295-301, doi: https://doi.org/10.1016/j.tiv.2008.12.014.

75. K. Dallmeier, E. A. Carlini, Anesthetic, hypothermic, myorelaxant and anti convulsant effects of synthetic eugenol derivatives and natural analogue, Pharmacol. 22 (1981) 113-127, doi: https://doi.org/10.1159/000137479.

76. M. Sayyah, A. Mandgary, Anticonvulsant effect of Ferula gummosa Root extract against experimental seizures, Iran. Biomed. J. 7 (2003) 139-143, doi: http://ibj.pasteur.ac.ir/ files/site1/user files b76aeb/admin-A-10-1-270-ac2797e. pdf (15. 3. 2018).

77. C. Peterson, J. Zhu, J. R. Coats, Identification of components of Osage orange fruit (Maclura pomifera) and their repellency to German cockroach, J. Essent. Oil Res. 14 (2002) 233-237, doi: https://doi.org/10.1080/10412905.2002.9699833.

78. J. Coats, C. J. Peterson, J. Zhu, T. Baker, L. Nemetz (lowa State University Research Foundation, ISURF) US Pat. Appl. 20030138471A1, 24 Mar. 2003, Biorational Repellents obtained from Triterpenoids for use against Arthropods, url: https://patents.google.com/patent/US20030138471A1 (15. 3. 2018)

79. J. W. Snyder, R. O. Poe, J. F. Stubbins, L. K. Garrettson, Acute maniac psychosis following the dermal application of $\mathrm{N}, \mathrm{N}$-diethyl-m-toluamide (DEET) in an adult, Clinical Toxicology 24 (1986) 429-439, doi: https://doi. org/10.3109/15563658608992605.

80. H. Qui, H. W. Jun, J. W. McCall, Pharmacokinetics, formulation and safety of insect repellent N, N-diethyl-3-methylbenzamide (deet): a review, J. Am. Mosq. Control Assoc. 14 (1) (1998) 12-27, cited in Coats et al., ref. 78.

81. G. Xing, P. Zhang, X. Zhang, Analysis of the chemical constituents of the essential oil of peel and flesh from Garcinia mangostana L, Shipin Kexue. 2 (2005) 291-294, cited in F. T. Martins, A. C. Doriguetto, T. C. de Souza, K. R. D. de Souza, M. H. dos Santos, M. E. C. Moreira, L. C. A. Barbosa, Comparison and Anti-inflammatory and Antioxidant Activities of the volatile oil from the fruit peel of Garcinia brasiliensis, Chem. Biodivers. 5 (2008) 251-258, doi: https://doi.org/10.1002/ cbdv.200890022.

82. P. Moongkarndi, C. Srisawat, P. Saetun, J. Jantaravinid, C. Peerapittayamongkol, R. Soi-ampomkul, S. Junnu, S. Sinchaikul, S. T. Chen, P. Charoenslip, V. Thongboonkerd, N. Neungton, Protective effect of Mangosteen extract against $\beta$-Amyloid-Induced cytotoxicity, oxidative stress and Altered Proteome in SK-N-SH cells, J. Proteome Res. 9 (2010) 2076 2086, doi: https://doi.org/10.1021/pr100049v. 
83. M. Rasheed, F. Afshan, R. M. Tariq, B. M. Siddiqui, T. Gulzar, A. Mahmood, S. Begum, K. Khan, Phytochemical studies on the seed extract of Piper nigrum Linn., Nat. Prod. Res. 19 (2005) 703-712, doi: https://doi.org/10.1080/1478641051 2331330657

84. K. Fidyt, A. Fiedorowicz, L. Strzadala, A Szumny, $\beta$-Caryophyllene and $\beta$-caryophyllene oxide - natural compounds of anticancer and analgesic properties, Cancer Med. 5 (10) (2016) 3007-3017, doi: https://doi.org/10.1002/cam4.816.

85. J. Legault, A. Pichette, Potentiating effect of beta caryophyllene on anticancer activity of alpha-humulene, isocaryophyllene and paclitaxel, J. Pharm. Pharmacol. 59 (2007) 16431647, doi: https://doi.org/10.1211/jpp.59.12.0005.

86. J. Gertsch, M. Leonti S. Raduner, R. Ildiko, C. Jian-Zhong, Beta-caryophyllene is a dietary cannabinoid, PNAS 105 (2008) 9099-9104, doi: https://doi.org/10.1073/ pnas.0803601105

87. L. Jirovetz, G. Buchbauer, M. B. Ngassoum, M. Geissler, Aroma compounds analysis of Piper nigrum and Piper guineense essential oils from Cameroon using solid-phase microextraction-gas chromatography, solid-phase microextraction-gas chromatography-mass spectrometry and olfactometry. J. Chromatogr. A, 976 (2002) 265-275, doi: https://doi. org/10.1016/S0021-9673(02)00376-X.

88. T. Odugbemi, A Textbook of Medicinal Plants from Nigeria, University of Lagos Press, Lagos, Nigeria, 2008, p. 594.

89. S. O. Nwozo, A. A. Ajagbe, B. E. Oyinloye, Hepatoprotective effect of Piper guineense aqueous extract against ethanol-induced toxicity in male rats, J. Exp. Integr. Med. 2 (2012) 7176, doi: https://doi.org/10.5455/jeim.241111.or.016.

90. J. Y. Chou, H-J. Chang, S.-K. Lee, H.-J. Kim, H. S. Chun, Amelioration of dextran sulfate sodium-induced colitis in mice by oral administration of $\beta$-caryophyllene, a sesquiterpene, Life Sci. 80 (2007) 932-939, doi: https://doi.org/10.1016/j. Ifs.2006.11.038.

91. S. L. da Silva, P. M. S. Figueiredo, T. Yano, Chemotherapeutic potential of the volatile oil from Zanthoxylum rhoifolium Lam leaves, Europ. J. Pharmacol. 576 (2007) 180-188, doi: https://doi.org/10.1016/j.ejphar.2007.07.065.

92. L. M. Leandro, M. F. de Sousa Vargas, P. C. S. Barbosa, J. K. O. Neves, J. A. da Silva, V. F. da Veiga-Junior, Chemistry and biological activities of terpenoids from Copaiba (Copaifera spp.) Oleoresins, Molecules 17 (2012) 3866-3889, doi: https:// doi.org/10.3390/molecules17043866.

93. K. R. Park, D. Nam, H. M. Yun, S. G. Lee, H. J. Jang, G. Sethi, S. K. Cho, K. S. Ahn, $\beta$-Caryophyllene oxide inhibits growth and induces apoptosis through the suppression of P13/AKT/ mTOR/S6K1 pathways and ROS-mediated MAPKs activation, Cancer Lett. 312 (2011) 178-188, doi: https://doi. org/10.1016/j.canlet.2011.08.001.

94. S. C. Benovit, L. L. Silva, C. A. Mallmann, B. Baldisserotto, E. M. Flores, B. F. Heinzmann, Anesthetic activity and bio-guided fractionation of the essential oil of Aloysia gratissima (Gillies \& Hook.) Tronc. in silver catfish Rhamdia quelen, Anais da Academia Brasileira de Ciencias 87 (2015) 1675-1689, doi: https://doi.org/10.1590/0001-37652015201.40223.

95. O. Tzakou, H. Skaltsa, Composition and antibacterial activity of the essential oil of Saturaja parnassica subsp parnassica, Planta Med. 69 (2003) 282-284, doi: https://doi. org/10.1055/S-2003-38487.

96. Y. Zhang, J. Zhao, J, Wang, T. Shan, Y. Mou, L. Zhou, J. Wang, Chemical Composition and antimicrobial activity of the volatile oil from Fusarium tricinctum, the endophytic fungus in Paris polyphylla var. yunnanensis, Nat. Prod. Commun. 6 (2011) 1759-1762, url: https://www.ncbi.nlm.nih.gov/pubmed/22224305.
97. M.-L. Tsai, C.-T. Wu, T.-F. Lin, W.-C. Lin, Y.-C. Huang, C.-H. Yang, Chemical Composition and Biological Properties of Essential Oils of Two Mint Species, Trop. J. Pharm. Res. 12 (2013) 577-582, doi: https://doi.org/10.4314/tjpr.v.12i4.20.

98. J. Li, F. Chen, J. Luo, GC-MS analysis of essential oil from the leaves of Psidium guajava, Zhong Yao Cai. 22 (1999) 78-80, url: https://www.ncbi.nlm.nih.gov/pubmed/12575048.

99. B. Joseph, R. Mini Priya, Review on nutritional, medicinal and pharmacological properties of guava, Psidium guajava Linn., Int. J. Pharma. Bio. Sci. 2 (2011) 53-69, url: http:// www.ijbs.net/volume2/issue1/pharma/5.pdf.

100.J. U. Chowdhury, N. C. Nandi, M. N. I. Bhuiyan, M. H. Mobarok, Essential Oil Constituents of the Rhizomes of Two Types of Curcuma longa of Bangladesh, Bangladesh J. Sci. Ind. Res. 43 (2008) 259-266, doi: https://doi.org/10.3329/ bjsir.v4312.970.

101.A. N. Thomas, S. Riazanskaia, W. Cheung, Y. Xu, R. Goodacre, G. L. P. Thomas, M. S. Baguneid, A. Bayat, Novel non-invasive identification of biomarkers by analytical profiling of chronic wounds using volatile organic compounds, Wound Repair Regen. 18 (2010) 391-400, doi: https://doi.org/10.1111/ j.1524-475X.2010.00592.x.

102.E. S. Fernandes, G. F. Passos, R. Medeiros, F. M. da Cunha, J. Ferrira, M. M. Campos, L. F. Pianowski, J. B. Calixto, Anti-inflammatory effects of compounds alpha-humulene and (-)trans-caryophyllene isolated from the essential oil of Cordia verbenacea, Europ. J. Pharmacol. 569 (2007) 228-236, doi: https://doi.org/10.1016/j.ejphar.2007.04.059.

103.L. Zhenhong, Chemical Analysis of Magnolia lilifora essential oil and its pharmacological function in nursing pregnant women suffering from decubitus ulcer, J. Med. Plants Res. 5 (2011) 2283-2288, url: www.academicjournals.org/journal/ JMPR/article-full-text-pdf/1A21EBC21462 (19. 3. 2018).

104.L. Z. Hong, Radix Linderae essential oil improving the immunity activities and preventing the occurrence of decubitus in aged people, J. Med. Plants Res. 5 (16) (2011) 3733-3738, www.academicjournals.org/journal/JMPR/article-full-text/ pdf/706171221489 (19. 3. 2018).

105.G. N. lyer, R. T. Sane, S. Menon (G. N. lyer, R. T. Sane, S. Menon) U. S. Pat. Appl. US2004/0223998A1, 11. Nov. 2004, Insect Repellent, url: https://patents.google.com/patent/ US20040223998. (19. 3. 2018.).

106.S. V. Kumar, R. A. Kumar, P. Mani, T. M. M. J. Bastin, G. Ravikumar, Mosquito Larvicidal, Oviposition deterrent and Repellent properties of Vitex negundo L extracts against Aedes aegypti, Anopheles stephensi and Culex quinquefasciatus, J. Pharm. Res. 4 (2011) 2060-2063, url: http://jprsolutions. info/newfiles/journal-file-56e79e8d764387.56060945.pdf (19. 3. 2018).

107.L. U. Franklin (XiMed Group PLC), U. S. Pat. Appl. 5977186, 2. 11. 1999. Terpene Treatments for killing lice and lice eggs, url: https://www.google.com/patents/US5977186 (19. 3. 2018).

108.M. B. Còstantin, P. Sartorelli, R. Limberger, A. T. Henriques, M. Steppe, M. J. P. Ferreira, M. T. Ohara, V. Emerenciano, M. J. Kato, Essential Oils from Piper cernuum and Piper regnellii : Antimicrobial Activities and Analysis by GC/MS and ${ }^{13}$ C-NMR, Planta Med. 67 (2001) 771-773, doi: https://doi. org/10.1055/s-2001-18363.

109.O. F. Obidi, A. O. Adelowotan, G. A. Ayoola, O. O. Johnson, M. O. Hassan, S. C. U. Nwachukwu, Antimicrobial activity of orange oil on selected pathogens, Int. J. Biotechnol. 2 (2013) 113-122, url: www://aessweb.com/pdf.files/ijb\%20 2(6),\%20113-122.pdf (19. 3. 2018).

110.C. Nardi, U Erboristeria Domani, 6 (1996) 58, cited in Markovic et al. (2008), ref. 111. 
111.I. S. Markovic, Z. A. Darmati, B. F. Abramovic, Chemical composition of leaf extracts of Stevia rebaudiana Bertoni grown experimentally in Vojvodina, J. Serb. Chem. Soc. 73 (2008) 283-297, doi: https://doi.org/10.2298/JSC0803283M

112.A. Ulubelen, G. Topcu, C. Eris, U. Sönmez, M. Kartal, S. Kurucu, C. Bozok-Johansson, Terpenoids from Salvia sclarea, Phytochem. 36 (1994) 971-974, doi: https://doi. org/10.1016/S0031-9422(00)90474-6.

113.J. Matthew, J. E. Thoppil, Chemical composition and mosquito larvicidal activities of Salvia essential oils, Pharm. Biol. 49 (2011) 456-463, doi: https://doi.org/10.3109/13880209 .2010 .523427 .

114.A. S. Salhab, H. H. Elayan, U. H. Stensrom, Crystalline isolation and physichochemical characterization of guaiol as a major constituent of an active spasmolytic fraction of the essential oil of Teucrium polium L., Dirasat 14 (1987) 93-101, cited in M. N. Garaibeh, H. H. Eleyan, A. S. Salhab, Anorexic effect of Teucrium polium in rats, Int. J. Crude Drug Res. 27 (1989) 201-210, url: https://www.researchgate.net/publication/259584129 (20. 3. 2018).

115.J. Tang, X.-R. Li, J. Han, Analysis of volatile components in Rhizome Zingibers, Zingiber Officinale Roscoe and Ginger Pee by GC-MS and chemometric resolution, J. Chinese Med. Res. Develop. 1 (2012) 47-53, url: www.academicpub.org/ DownLoadPaper.aspx?paperid =1289 (20. 3. 2018).

116.C. C. Carpenter, J. A. Heinlein, M. B. Sulzberger, R. L. Baer, Scabies and Pediculosis treated with Benzyl Benzoate, DDT, Benzocaine Emulsion, J. Investig. Dermatol. 7 (1946) 93-98, doi: https://doi.org/10.1038/jid.1946.8.

117.M. S. Kumar, S. Maneemegalai, Evaluation of Larvicidal Effect of Lantana camara Against Mosquito species Aedes aegypti and Culex quinquefasciatus, Adv. Biol. Res. 2 (2008) 39-43, url: https://pdfs.semanticscholar.org/ b6f5/53f41797971b2748d64b5f67f810b9b4ff44.pdf $\quad$ (20. 3. 2018).

118.A. A. Rahuman, G. Gopalakrishnan, B. S. Ghouse, S. Arumugan, B. Himalayan, Effect of Feronia limonia on mosquito larvae, Fitoterapia 71 (2000) 553-555, cited in M. N. Abubakar, R. T. Majinda, GC-MS analysis and preliminary antimicrobial activity of Albizia adianthifolia (Schumach) and Pterocarpus angolensis (DC,. Medicines 3 (2016), doi: https://doi.org/10.3390/medicines3010003.

119.J.-F. Rontani, G. Giusti, Photosensitized oxidation of phytol in seawater, J. Photochem. Photobiol. A Chem. 42 (1988) 347355, doi: https://doi.org/10.1016/1010-6030(88)80078-9.

120.B. J. Adedoyin, S. O. Okeniyi, S. Garba, L. Salihu, Cytotoxicity, antioxidant and antimicrobial activities of essential oils extracted from Euphorbia heterophylla plant, Topclass J. Herbal Med. 2 (2013) 84-89.

121.Pubchem, Open Chemistry Database, compound summary CID 10453 (2005), url: https://pubchem.ncbi.nlm.nih.gov/ compound/isophytol (20. 3. 2018).

122.S. N. Abd Malek, A. N. Wahab, H. Yaacob, H, S. K. Shin, H. S. Lai, L. G. Serm, S. N. S. A Rahman, Cytotoxic activity of Pereskia bleo (Cactaceae) against selected human cell lines, Int. J. Cancer Res. 4 (2008) 20-27, doi: https://doi.org/10.3923/ ijcr.2008.20.27.

123. M. Kagoura, C. Matsui, M. Morohashi, Phytol is a novel tumor promoter on ICR mouse skin, Jpn. J. Cancer Res. 90 (1999) 377-384, doi: https://doi.org/10.1111/j.1349-7006.1999. tb00758.x.

124.P. Olofsson, M. Hultqvist, R. Holmdahl (Manelli Denison \& Selter PPLC) US Pat. Appl. 20110015278, 20 Jan 2011. Phytol as a cholesterol lowering agent, www.patentsencyclopedia.com/app/20110015278 (20. 3. 2018).
125.F. B. Da Costa, S. Albuquerque, W. Vichnewski, Diterpenes and synthetic derivatives from Viguiera aspilloides with trypanomicidal activity, Planta Med. 62 (1996) 557-559, cited in N. Uchiyama, Antichagasic Activities of Natural Products against Trypanosoma cruzi, J. Health Sci. 55 (2009) 31-39, doi: https://doi.org/10.1248/jhs.55.31.

126.S. Gregersen, P. B. Jeppesen, B. J. J. Holst, K. Hermansen, Anti-hyperglycemic effect' of stevioside in type 2 diabetic subjects, Metabolism 53 (2004) 73-76, doi: https://doi. org/10.1016/j. metabol.2003.07.013.

127.P. Chan, B. Tomlinson, Y.-J. Chen, J. C. Liu, M.-H. Hsieh, J.-T. Cheng, A double-blind placebo-controlled study of the effectiveness and tolerability of oral stevioside in human hypertension, Brit. J. Clin. Pharmacol. 50 (2000) 215-220, doi: https://doi.org/10.1046/j.1365-2125.2000.00260.X.

128.P. B. Jeppesen, S. Gregersen, C. R. Poulsen, K. Hermansen, Stevioside acts directly on pancreatic beta cells to secrete insulin; actions independent of cyclic adenosine mono phosphate and adenosine triphosphate-sensitive $\mathrm{K}^{+}$- channel activity, Metabolism 49 (2000) 208-214, doi: https://doi. org/10.1016/S00260-0495(00)91325-8.

129.S. Gregersen, K. Hermansen, P. B. Jeppesen (Stevia Aps), Pat. Appl. PCT/DK2001/000075, 1 Feb 2001, A substance for use in a dietary supplementation or for the preparation of a medicament for the treatment of non-insulin dependent diabetes mellitus, hypertension and /or the metabolic syndrome, https://encrypted.google.com/patents/WO2001056959A1?$\mathrm{Cl}=\mathrm{es}(20.3 .2018)$

130.W. Tan, Pat. Appl. CA2606472A1, 24 Nov 2005, Use of kauranes compounds in the manufacture of medicament, https://patents.google.com/patent/CA2606472A1?cl=en (20. 3. 2018).

131. A. D. Russell, Mechanism of bacterial resistance to non-antibiotics: food additives and food pharmaceutical preservatives, J. Appl. Bacteriol. 71 (1991) 191-201, doi: https://doi. org/10.1111/j.1365-2672.1991.tb0447x

132.G. Agoramoorthy, M. Chandrasekaran, V. Venkatesalu, M. J. Hsu, Antibacterial and antifungal activities of fatty acid methyl esters of the blind-your- eye mangrove from India, Braz. J. Microbiol. 38 (2007) 739-742, doi: https://doi. org/10.1590/S1517-83822007000400028.

133. V. Aparna, K. V. Dileep, P. K. Mandal, P. Karthe, C. Sadasivan, M. Haridas, Anti-inflammatory property of $n$-hexadecanoic acid, Structural evidence and kinetic assessment, Chem. Biol. Drug Design 80 (2012) 434-439, doi: https://doi. org/10.1111/j.1747-0285.2012.01418.x.

134.P. Kumar, S. Kumaravel, C. Lalitha, Screening of antioxidant activity, total phenolics and GC-MS study of Vitex negundo, Afr. J. Biochem. Res. 4 (2010) 191-195, url: www.academicjournals.org/article/article1380110714.

135.F. R. Yu, X. Z. Lian, H. Y. Guo, P. M. McGuise, R. D. Li, R. Weng, F. H. Yu, Isolation and characterization of methyl ester and derivatives from Euphorbia kansui (Euphorbiaceae) and their inhibitory effects on the human SGC-7901 cells, J. Pharm. Pharm. Sci. 8 (2005) 528-535, PMID: 16401398.

136.E. P. Awa, S. Ibrahim, D. A. Ameh, GC/MS analysis and antimicrobial activity of diethyl ether fraction of methanolic extract from the stem bark of Annona senegalensis Pers, Int. J. Pharma. Sci. Res. 3 (2012) 4213-4218, doi: https://doi. org/10.13040/IJPSR.0975-8232.3(11).4213-18.

137. G. Zhao T. D. Etherton, K. R. Martin, J. P. Vanden Heuvel, P. J. Gillies. S. G. West, P. M. Kris-Etherton, Anti-inflammatory effects of polyunsaturated fatty acids in THP-1-cells, Biochem. Biophys. Res. Commun. 336 (2005) 909-917, doi: https:// doi.org/10.1016/j.bbrc.2005.08.204. 


\title{
SAŽETAK
}

\author{
Potencijal sastojaka esencijalnog ulja iz lišća biljke \\ Adenia cissampeloides za primjenu u medicini i kao pesticida \\ Modupe Ogunlesi, Wesley Okiei, Edith Ofor i Anthony Eniola
}

\begin{abstract}
Adenia cissampeloides (Panch. ex. Hook.) Harms je biljka koja se u alternativnoj medicini primarno upotrebljava za ublažavanje hipertenzije i nekoliko drugih bolesti. Provedena je izolacija i GC-MS analiza pet esencijalnih ulja frakcijski izdvojenih za vrijeme hidrodestilacije osušenog lišća koja je trajala preko četiri sata. Ulja su sadržavala fitol, $\alpha$-linolensku kiselinu, $n$-heksadekanoičnu kiselinu, heksahidrofarnezil aceton, (13S)-8,13-epoksi-labd-14-en, kaur-16-en, gvajol, $\alpha$-gurjunen i $\alpha$-elemen. Provedena je rasprava i o nekoliko različitih bioaktivnosti sastojaka kao i o njihovoj potencijalnoj primjeni u medicini, farmaciji i industriji pesticida. Sastojci izolirani iz A. cissampeloides postoje i u esencijalnim uljima nekih drugih biljaka. Bioaktivnosti takvih biljaka upućuju na to da postoje i druge moguće primjene A. cissampeloides.
\end{abstract}

\section{Ključne riječi}

Adenia cissampeloides, GC-MS, ljekovito bilje, esencijalna ulja, bioaktivnost

Chemistry Department

University of Lagos

Lagos, Nigerija
Pregledni rad

Prispjelo 28. travnja 2018. Prihvaćeno 20. srpnja 2018. 